\title{
KARL BARTH SE ONTWERP VIR DIE ESKATOLOGIE
}

\section{INLEIDING:}

\author{
DS. ADRIO KÖNIG
}

Op 10 Desember 1968 is die belangrikste teoloog van hierdie eeu, Karl Barth, in die ouderdom van 82 jaar oorlede. Sy oorlye het alle hoop finaal laat kwyn dat hy tog nog iets meer aan die eskatologie sou kon doen. Dit bly dus in sekere sin die ongeskrewe hoofstuk in sy Kirchliche Dogmatik. En dit is besonder jammer dat hy juis op hierdie gebied, waar daar in die afgelope 70 jaar soveel verwarring geheers het, nie sy volle bydrae kon lewer nie.

En tog vra Barth tereg in die voorwoord tot die Fragment (K.D. IV 4):1) " . . . ob sie denn nicht gemerkt hätten, wieviel gerade aus dem so besonders begehrten Bereich der Eschatologie den früheren Bänden indirekt und z.T. doch auch direkt zu entnehmen sei?" Alhoewel in die „frühere Bänden" nie 'n volledig uitgewerkte eskatologie te vinde is nie, is daar tog 'n ontwerp of 'n patroon waarin belangrike gesigspunte vir dié leerstuk inbegrepe is. Hierdie ontwerp vir die eskatologie sal vervolgens geskets word.

\section{DIE ONTWIKKELING:}

Daar is ' $n$ duidelike ontwikkelingsgang in Barth se eskatologiese denke. Hierin moet vier fases onderskei word waar daar telkens ' $n$ meer of minder belangrike klemverskuiwing ingetree het, naamlik:

(i) die eerste uitgawe van die Römerbrief (1919);

(ii) die tweede en daaropvolgende uitgawes (1922);

(iii) K.D. II 1 tot K.D. IV 1; en

(iv) K.D. IV 3.

Eers in K.D. IV 3 neem sy ontwerp die finale vorm aan. Die eerste drie fases sal dus heel kort ondersoek word.

\section{A. DIE EERSTE UITGAWE VAN DIE RöMERBRIEF (1919):}

Hierdie kommentaar moet in sy geheel in 'n sekere sin slegs as 'n voorstadium tot Barth se teologiese denke gesien word byna soos die Christliche Dogmatik van 1928 tot sy Kirchliche Dogmatik. Barth verklaar self in 1922 in die voorwoord tot die tweede uitgawe dat „van jener ersten sozusagen kein Stein auf dem andern geblieben ist"'). Van sy eskatologiese visies geld dit ten diepste.

1. K.D. IV 4, p. VII.

2. Der Römerbrief, 1954, p. VI. 
In 1919 bring Barth dan ook weinig nuwe insigte vir die eskatologie na vore. Hy beweeg nog volkome in die lyn van Ragaz $^{3}$ ). Hy beklemtoon die toekoms as dit wat nog nie werklikheid is nie, as die heerlikheid wat nog kom. Hy praat van die groot vreugde wat voor die deur is en wat ons huidige sugtende bestaan draaglik maak ${ }^{1}$ ). Trouens 1919 se eskatologiese uitsprake het géén bydrae gelewer tot die aardbewing wat (die res van) hierdie kommentaar in die teologiese wêreld veroorsaak het nie. Dit is dan ook opvallend dat wanneer Barth later krities terugkyk op sy eskatologiese visies in sy vroeëre werke, hy glad nie eers melding maak van 1919 se standpunte nie ${ }^{5}$ ).

\section{B. DIE TWEEDE UITGAWE VAN DIE RÖMERBRIEF (1922):}

In hierdie uitgawe gaan daar 'n aardbewing deur die eskatologiese patroon van 1919. Hy breek met die skema: verlede-hedetoekoms, en wel só dat veral die toekoms wat in 1919 so spontaan gefunksioneer het, verdwyn. Die volgende voorbeelde sal dit verduidelik:

(i) Wat in 1922 gebeur, vind mens in 'n vergelyking van die opskrifte waaronder hy in 1919 en dan in 1922 Rom. 8 uitlê:

\section{9}

Rom. 8:1-11:

Rom. 8:12-27:

Rom. 8:28-39:
Die Vergangene

Die Gegenwărtige

Die Zukünftige
1922

Die Entscheidung

Die Wahrheit

Die Liebe.

(ii) In 1919 sluit Barth doelbewus elk van die laaste vier paragrawe waarin hy Rom. 8:17, 18 verklaar, met 'n verwysing na die „Zukunft Gottes” af - en dit is elke keer onmiskenbaar horisontaal (dit wil sê werklik toekoms-tig) bedoel soos onder andere uit die volgende aanhaling blyk: „Aber als Mitlebenden im ,Leben des Christus', das van seiner Auferstehung aus durch die Zeiten hindurch in die künftige Vollendungswelt hineinwächst, kann uns gerade auf diese Frage die Antwort nich fehlen".

Hierdie ganse verwysingspatroon na die "Zukunft Gottes" ontbreek egter in die tweede uitgawe.

(iii) Barth se uitleg van Rom. 8:17, 18 in 1919 kom kortliks hierop neer dat ons nou ly om eens in die volle heerlikheid te deel - dus onmiskenbaar horisontaal-histories gesien. Uitdruk-

3. H. Berkhof: Twintigste-eeuwse eschatologie tussen Bijbelgezag en levensbesef, in: Vox Theologica 4, Juli 1967.

1. Só veral in sy uitleg van Rom. 8.

5. K.D. II I, p. 713-719. Dit sal later blyk dat daar tog wel beslissende verbande tussen 1919 en sy finale (gewysigde) ontwerp bestaan. En dan sal die vraag na vore kom waarom Barth nie op hierdie vroeëre posisies teruggryp nie. 
kinge soos die volgende is onmiskenbaar toekoms-tig gerig: „Gott ist der Kommende"; die ,kommende Sieg" (wat teenoor die huidige lyding gestel word); „Diese gewisse Aussicht in die Zukunft ist's nun, die uns den Widerspruch unserer jetztigen Situation verstăndlich . . . macht;" "... sehen wir alle Zeit wie durch eine Spalte hinein in diese bevorstehende grosse Freude".

Hierteenoor staan sy uitleg van dieselfde tekste in die tweede uitgawe waarin die teenwoordige tyd gesien word as ,die Zeit der eben im Leiden sich an aus offerbarenden Herrlichkeit" en waarin tyd tweekeer omskryf word as "die Negation der Ewigkeit". Die antwoord op die lyding waarin ons tans verkeer, is nie meer die toekoms-tige heerlikheid nie, maar „die Betrachtung sub specie aeterni, das Schauen von Gott aus". Die toekoms speel in hierdie uitleg eintlik geen rol nie. Tiperend is ook die volgende uitspraak: ". . . leidend und gerade darin triumphierend ..."

'n Vergelyking van die verskille in Barth se vertaling van Rom. 8:18, 19 in 1919 en in 1922 bring dieselfde feit na vore: 1919 1922

8:18(b): „die sich in der Zukunft an uns offenbaren soll."

8:19(a): „Den auch das gespannte Harren der Schöpfung wartet auf diese Offenbarung."

(iv) In beide uitgawes tref ons radikale uitsprake oor die eskatologiese karakter van die evangelie aan. In die eerste uitgawe is dit egter onmiskenbaar 'n toekoms-uit-spraak naamlik: „Dein Leben aber ist im Christus und das Wesen dieses Lebens liegt eben in seiner Zukunftsperspektive, in seiner der neuen Welt zugewandten Zielstrebigkeit und ohne diese Perspektive ist alles sogenamten „Gottvertrauen" eitel heidnischer Schicksalsglaube".

Die beroemdgeworde ,eskatologiese" uitspraak in die tweede uitgawe bevat (en dit is veelseggend!) egter nie meer die woord toekoms nie: „Christentum, das nicht ganz und gar und restlos Eschatologie ist, hat mit Christus ganz und gar und restlos nichts zu tun". Juis hierdie feit gee aanleiding tot die laaste punt.

(v) Die betekenis van die begrip „eskatologie" het tussen 1919 en 1922 skynbaar 'n merkwaardige verandering in Barth se denke ondergaan. 'n Kort samevatting van sy uitleg op Rom. 8:17-27 en Rom. 13:11-12 (dié gedeeltes in die Romeinebrief wat by uitstek geleentheid bied vir eskatologiese aantekeninge) sal dit aan die lig bring. 
In 1919 is hierdie gedeeltes nog sterk toekoms-tig uitgelê met indelings soos:

(i) „Es gab eine Stunde,

(ii) Es kam eine andere Stunde und die ist jetzt da,

(iii) Es wird eine andere Stunde kommen, aber die ist jetzt noch nicht da, da wird der neue Himmel und die neue Erde, deren wir jetzt warten, vorhanden sein"').

In die paragraaf wat volg op die uitspraak onder punt (iii) volg dan na mekaar sewe keer die woordjie „dann" - 'n aanduiding van hoe duidelik hier sprake is van wat nou nog nie voorhande is nie, maar dàn - op 'n bepaalde tydstip in die toekoms - sal wees.

In 1922 het dit heeltemal verander en verdwyn hierdie indeling: verlede, hede, toekoms (vergelyk punt (i) hierbo), en ook die woord „dann”, en dan sien sy verklaring wat in 1919 wesenlik toekomsbetrokke was, kortliks as volg daaruit:

Rom. 8:17-27. Die ongehoorde wonder daarvan dat ons kinders van God kan wees; ons huidige lyding is draaglik omdat Jesus Christus dit alreeds gedra het; die mens in konflik vertoon 'n merkwaardige verlange om die uiterstes in die mikrokosmos en makrokosmos na te vors - omdat ons deel in hierdie konfliksituasie van die skepping; gevolglik wissel ons tussen optimisme en pessisisme solank ons geen uitsig van God uit het nie. (Wanneer hier tog tweekeer van toekoms sprake is, naamlik in verse 20-22 en in vers 23 se verklaring, word toekoms elke keer omskryf as: „Eine Zukunft die nie und nimmer Zeit sein wird”.) God alleén weet meer van die skepping as dat dit sugtend is, máár God is in die hemel en jy op die aarde. Ons is gebroke wesens, ons sug - hierop val al die klem. Wanneer die „opstanding van die dode" tog wel 'n keer ter sprake $k o m,{ }^{8}$ ) dan is die uitleg daarvan uitermate duister en alles behalwe op die toekoms gerig.

Die radikale klimaatsverandering tussen 1919 en 1922 kan hier duidelik aangevoel word.

Die bevreemdende is egter nou dat juis 1922 se uitgawe die beroemdgeworde uitspraak oor die eskatologie bevat, naamlik: „Christentum, das nicht ganz und gar und restlos Eschatologie ist, hat mit Christus ganz und gar restlos nichts zu tun".

Ek meen dat die verband waarin hierdie uitspraak voorkom, egter 'n aanduiding gee van die nuwe inhoud wat die eskatologie in 1922 vir Barth gekry het. Hy doen naamlik hierdie uitspraak

\footnotetext{
G. Der Römerbrief (eerste uitgawe pp. 393-4. Kursivering van Barth!

?. Der Römerbrief (tweede uitgawe), p. 294 en 296.

8. Idem., p. 296.
} 
terwyl hy besig is om oor die onvolmaaktheid van ons lewe te handel, oor die incognito van die verlossing, oor die hele skepping wat sug, oor Christus wat ons slegs as die gekruisigde ken, oor die onaanskoulikheid, onsigbaarheid en onmoontlikheid van ons nuwe lewe, oor die feit dat ons nie mér as hopendes kan wees nie, dat die hoop die oplossing van die raaisel van ons bestaan is (N.B. nié die verwesenliking van die hoop nie, maar die hoop sélf; die verwesenliking van die hoop in 'n toekomsdimensie kom glad nie in sig nie), dat ons deur die hoop eksistensieel sien wat ons tog (nie: „nog” nie!) nie sien nie. In hierdie verband vind ons die reeds genoemde radikale uitspraak oor die noodsaaklike eskatologiese karakter van die Christendom. Dit is myns insiens duidelik dat "eskatologie" in hierdie verband in werklikheid beteken: ons situasie as onvolmaak, incognito, al sugtende, begrens en gebroke, teenoor God as die volmaakte, onbegrensde, triomferende. MAAR hieraan is geen tydsgedagte verbonde en hierdeur word geen toekoms-perspektief geopen nie. Mens sou in hierdie terme die christelike situasie kon omskryf as die situasie van onvolmaak, incognito, ongebroke en sugtende in sigself, maar (weliswaar bedek en onsigbaar) volmaak, geheel en triomferend in en deur God. Dit alles egter gelyktydig en nie opeenvolgend nie.

In die lig hiervan moet die radikale uitsprake by die verklaring van Rom. 13:11-12 in 1922 gesien word, naamlik wanneer hy met verwysing na Mark. 13:23 (nét die Vader weet die uur) skryf: „Gellen denn gar niemandem die Ohren? Will das unnütze Gerede von der ,ausgebliebenen" Parusie denn gar nicht aufhören? Wie soll den „ausbleiden” was seiner Begriff nach überhaupt nicht „eintreten" kann? Denn kein zeitliches Ereignis, kein fabelhafter "Weltuntergang", ganz und gar ohne Beziehung zu entwaigen geschichtlichen, tellurischen oder kosmischen Katastrophen ist das im neuen Testament verkündigte Ende, sondern wirklich das Ende, so sehr das Ende, dass die neunzehnhundert Jahre nicht nur wenig sondern nichts zu beduten haben, was seine Nahe oder Ferne betrifft, so sehr das Ende dass schon Abraham diesen Tag sah und sich freute".

Nog 'n uitspraak in hierdie verband is baie belangrik. Net op die vorige bladsy skryf Barth onder andere die volgende oor die tyd as kronologies gekwalifiseer: „,Jetzt ist unsre Errettung näher als damals, als wir gläubig wurden? Immer besteht diese Spannung swischen dem „damals" unsres gerurigen Seins und dem ,jetzt" der störenden Erinnerung an unser Nicht-Sein, immer die Spannung zwischen den Zeiten der „schon" stattgefundenen Offenbarung . ... und des Zeiten des Gedenkens, Erwartens und Hinblickens auf das existensielle Ereigniswerden des 
wir vermeintlich „schon" Bestehenden, auf den ewigen Augenblick der Erscheinung, der Parusie, der Gegenwart Jesu Christi. Mit den berühmten neunzehnhundert Jahren Kirchengeschichte aber, die die Parusie bekanntlich "noch nicht" gebracht haben, hat diese Spannung zwischen den Zeiten soviel und so wenig zu tun wie etwa mit den Wochen oder Monaten, die der Römerbrief im Gepäck der Phöbe zwischen Korinth und Rom unterwegs gewesen ist ..."

Uit dit alles volg dat die eskatologie vir Barth in 1922 nie meer allereers te doene het met dit wat in die toekoms op ons wag en eenmaal werklikheid sal word nie. Veeleerder gaan dit om die ewigheid wat krities teenoor die tyd staan. As hier nog van die einde sprake is, is dit die einde wat in Christus aangebreek het, God wat in Christus naby ons gekom het.

Is dit nie wat die volgende uitspraak beteken nie? „Unvergleichlich steht der ewige Augenblick allen Augenblicken gegenüber, gerade weil er aller Augenblicke transzendentaler Sinn ist. Und unvergleichlich die „Errettung”, der „Tag” das Reich Gottes allen Zeiten, gerade weil es aller Zeiten Erfüllung ist"10).

In 1940 verklaar Barth self dat hierdie standpunt eensydig was, ${ }^{11}$ ) dat die Bybelse begrip van die ewigheid - wat ook Nachzeitlich is ${ }^{12}$ ) - nie in sy volle Bybelse betekenis gesien is nie en veral: "Man sicht aber auch, wie ich dabei gerade an dem Besonderen dieser Stelle (nl. Rom. 13:11 v., onder andere: "... want die saligheid is nou nader by ons as toe ons gelowig geword het. Die nag het ver gevorder en dit is amper dag"), nämlich an der Teleologie, die sie der Zeit zuschreibt, an ihrem Ablauf zu einem wirklichen Ende hin, mit viel kunst und Beredsamkeit vorbeigegangen bin. Und man sieht vor Allem mit Erstaunen, dass in meiner Auslegung ausgerechnet das einseitig überzeittiche Verständins Gottes, das zu bekämpfen ich ausgezogen war (soos dit naamlik geheers het in die 19de eeuse piëtistiese teologie), als allein greifbares Ereignis auf dem Plane blieb ... (en) dass zwar der Optimismus des neuprotestantischen Zeitbegriffs . . . aufs neue bestätigt worden sei ... Und gerade hier konnte man ... . darüber trauern, dass der Schwung, den diesen Hoffnung gerade in ihrer Beziehung auf die Zeit in das zeitlich Christiche Denken und Leben hineingebracht hatte, wieder bedroht war und ... zu verkümmern drohte". En verder: „,so war es doch nicht nötig und recht, dies in der Weise zu tun, dass man der ganzen christlichen Lehre ebenso diese eine Spitze

\footnotetext{
?. Idem., p. 483.

10. Idem. p. 482.

11. K.D. II I, p. 715 .

12. Idem., p. 709v.
} 
gab, wie die vorangeganene ihr ihre alleinige Spitze in der vermeintliche Erkenntnis der Gegenwart Gottes hatte gehen wallen"13). En as Barth op die volgende bladsy waarsku teen "Steckenpferdreiten" (stokperdjie-ryery), het hy ongetwyfeld nie net Schweitzer c.s. in die oog nie, maar sy eie eskatologiese en ewigheidsvisies van 1922.

\section{K.D. II 1 TOT IV 1:}

\section{Korreksie op 1922:}

Die belangrikste korreksie wat Barth aan 1922 se eskatologiese standpunte aanbring, geskied in 1940 K.D. II 1 wanneer hy in die leer oor God die ewigheid van God behandel. Hy beklemtoon in hierdie behandeling die feit dat die Bybelse ewigheidsbegrip nie net antiteties teenoor die tyd staan en die negasie van die tyd is nie ${ }^{14}$ ) en dat ewigheid en tyd nie slegs in die verhouding stare-fluere teenoor mekaar staan nie. Dit alles was min of meer sy standpunt in 1922 met die gevolg dat hy die ewige God en 'n egte toekoms beswaarlik met mekaar in verband kon bring.

Tans stel hy dit dat die ewigheid in die Bybel deurgaans in 'n positiewe verhouding tot die tyd gestel word, dat die ewigheid 'n bepaalde „Potentialität zur Zeit" het (immers is dit dan nie die ewige God wat in Christus mens geword het en dus self "zeitlich" en Homself dus in vryheid onderwerp het aan die tyd nie); dat ewigheid „,nicht als reine Zeitlosigkeit” verstaan kan word nie, maar dat ons inteendeel van die ,Zeitlichkeit der Ewigkeit " moet praat, en God se „Ewigkeit die eigentliche Zeitlichkeit" noem ${ }^{15}$ ).

Die verskil tussen tyd en ewigheid is nie dat daar in die ewigheid geen onderskeid tussen beweging en doel, tussen verlede, hede en toekoms, tussen „,nog nie”, ,alreeds" en „,nie meer nie" is nie, maar slegs dat daar in die ewigheid (anders as in die tyd) geen konkurrensie en stryd tussen hierdie onderskeidinge is nie $\left.{ }^{16}\right)$. Daar is inderdaad beweging en rigting en koers in die ewigheid. Daar is inderdaad oorsprong, weg en doel.

Trouens in K.D. III 2 gaan Barth nog veel verder. Hy volstaan dan nie meer met „die Zeitlichkeit der Ewigkeit" nie, maar praat van "die ewige Zeit" wanneer hy handel oor Christus se tyd as God se tyd. Dit is nou nie meer ewigheid wat teenoor tyd staan nie, maar Christus (God) se tyd teenoor ons tyd. Die verskil bly egter dieselfde as die tussen ewigheid en tyd in 1940: Christus

13. K.D. II I, p. 716-717.

11. Idem., p. $688 \mathrm{v}$.

1.5. K.D. III 2, p. 525

16. Behalwe die reeds genoemde deel in K.D. II I, vergelyk ook K.D. III 2, p. 677. 
se tyd het verlede, hede en toekoms net soos ons tyd, maar sy verlede, hede en toekoms konkurreer nie met mekaar en sluit mekaar nie uit nie. Ons toekoms het nog nie aangebreek nie dit geld egter nie vir Christus se toekoms nie. Ons verlede bestaan nie meer nie - dit geld egter nie van Christus se verlede nie. „Diese Aufhebung der Schranken ihres Gestern, Heute und Morgen, ihres Damals, Jetzt und Dereinst ist die Eigentumlichkeit der Zeit des Menschen Jesus, weil sie laut ihres Offenbarwerdens in der Osterzeit als solche auch die Zeit Gottes, die ewige Zeit ist" ${ }^{\prime \prime}$ ).

In die interessante onderskeiding tussen God se Vor-, Überen Nachzeitlichkeit werk hy dan die tydsbetrokkenheid (Zeitlichkeit) van die ewigheid uit. Veral onder die Nachzeitlichkeit van God kom die egte toekoms (en dus ruimte vir die toekoms as eskatologiese kategorie) dan ter sprake wat in 1922 se Römerbrief gemis is. „Wir gehen ihm (nl. God) entegen wie wir von ihm herkommen, wie wir ihn begleiten dürfen" ${ }^{18}$ ). "Gott ist auch die nachzeitliche Ewigkeit: die Ewigkeit, der wir entgegengehen und eben insofern ist er der Gott aller Hoffnung, die Ruhe, die seinem Volk vorhanden, bereitet und zugesagt ist, in die es noch nicht gekommen ist, aber kommen wird . . . So haben wir, idem wir ihn haben, wirklich Alles: auch das was wir noch nicht haben"19). Die onderstreepte woorde toon duidelik die korreksie op 1922 se tydlose en toekomslose ewigheid. Hier kom die teleologie en die doel van die eskatologie weer in sig.

\section{Verdere uitbouing:}

In K.D. III 2, onder die opskrif ,Jesus, der Herr der Zeit", handel Barth breedvoerig oor die verlede, hede en toekoms van Jesus Christus ${ }^{20}$ ). Die toekoms van Jesus (en gevolglik die hoop van die gemeente) is in die Nuwe Testament net so belangrik as sy verlede en sy hede - nie minder belangrik of meer belangrik nie. Die Nuwe Testament ken geen geleidelike wêreldontwikkeling wat sy koms oorbodig maak nie. Sonder die verwagting van sy koms in heerlikheid verlaat mens die grond ,auf dem die Christliche Kirche sich ehrlicherweise christliche Kirche kann. . . . Wir haben hier nur festzustellen, dass auch mit der Hoffnung, auch mit der Erwartung . . . des Menschen Jesus das Ganze steht und fällt"'11).

\footnotetext{
1i. K.D. III 2, p. 557

14. K.D. II I, p, 709 .

19. Idem.. p. 711. Kursivering van my.

=4. K.D. III 2. p. 582-616.

2 . Idem., p. 592-593.
} 
In K.D. III 2 en IV 1 onderskei Barth twee fases in wat hy Christus se koms in heerlikheid noem, naamlik sy opstanding en sy wederkoms ${ }^{22}$ ). In sy opstanding begin sy koms in heerlikheid. Dit word tydelik onderbreek deur die tussentyd, maar sodra die doel van die tussentyd, naamlik die bestaan en die diens van die gemeente, bereik is, sal dieselfde gebeurtenis (naamlik sy koms in heerlikheid) voortgesit word deur sy wederkoms ${ }^{23}$ ). Tans praat Barth nog van die eerste en die tweede Parusie met die tussentyd (wat hy liewer die eindtyd wil noem) as die "Intervall" wat die tweede Parusië skei. „Was ein einziger Geschehen sein konnte - man möchte wohl denken: sein musste - tritt nun dennoch auseinander":-14).

Alhoewel Barth dit in hierdie fase van sy eskatologiese denke nog so stel dat die tussentyd 'n pouse is wat die éen koms is neerlikheid tydelik onderbreek, beteken dit egter tog nie dat hy hierdie tyd as 'n vakuum voorstel, as 'n tyd waarin Christus af wesig is, as 'n tyd waarin die bruilofsgaste moet vas en treur nie. Hy noem tans alreeds die opvallende feit dat in die Johannesevangelie „Ostern, Himmelfahrt, Pfingsten und Parusie gewissermassen in perspektivischer Verkürzung . . . als ein einziges Ereignis zusammengesehen werden"25). Barth sien hier egter nog nie, soos in sy finale ontwerp, die teenwoordigheid van Jesus in die tussentyd as nog 'n vorm van sy Parusie nie. Daarom kan hy nog die wederkoms sondermeer as Parusie aandui. Dit is dan ook die belangrikste ontwikkeling in K.D. IV 3 waarin sy finale ontwerp aangetref word. Vir die res bly die betekenis wat hy aan die opstanding en die wederkoms heg, skynbaar onveranderd, sodat dit later bespreek kan word sonder om dit in fases in te deel.

\section{K.D. IV 3:}

Dit is belangrik om daarop te let dat Barth juis onder die opskrif „Die Verheissung des Geistes" 26 ) tot die finale vorm van sy eskatologiese ontwerp kom. Juis hierin is K.D. IV 3 'n ontwikkeling op die vorige fase, dat hy nou met helderheid ook die koms en teenwoordigheid van die Heilige Gees in die tussentyd as 'n vorm van die Parusie van Jesus Christus sien „... das Osterereignis ist . . . sein neues Kommen als der zuvor Gekommene"27).

\footnotetext{
22. Idem., p. 589 .

23 . Idem.. 587.

$2 i$ K.D. IV 1, p. 821

25 K.D. III 2, p. 598.

26. K.D. IV 3, s. 69,4 , p. $317-424$

27. K.D. IV 3, p. 335. Kursivering van Barth.
} 
Barth sien die Parusie of wederkoms van Christus dus as één gebeurtenis wat sig in drie vorme voltrek.

Enersyds één Parusie. „Das Neue Testament weiss, was den Umfang und Gehalt dieses Ereignisses betrifft, nur um eine Wiederkunft Jesus Christi, nur um ein neues Kommen des zuvor Gekommenen ... Dass aber dieses sein neues Kommen ... zu den ... verschiedenen Zeiten, ... . in verschiedenen Formen geschieht, ist damit nicht ausgeschlossen. Es ligt freilich Alles daran, dass man es als das in allen seinen Formen kontinuierliche eine Geschehen sieht und versteht"28). Hierdie drie vrome, naamlik die opstanding van Jesus, sy koms in die uitstorting van die Heilige Gees en sy "Letzte Wiederkunft" ${ }^{29}$ ) is dus drie vorme van één gebeurtenis: sy wederkoms.

Andersyds beklemtoon Barth ook die drie vorme wat onderskei moet word, „Die Wiederkunft Jesus Christi im Osterereignis is nach dem Neuen Testament noch nicht als solche seine Wiederkunft in Heilige Geiste und erst recht noch nicht seine Wiederkunft am Ende alle Tage"30).

Die Parusie word dus oor die drie tydsvorme versprei: Jesus Christus het alreeds weer gekom in sy opstanding, Hy is tans by ons in die Heilige Gees en Hy sal weer kom in sy laaste wederkoms.

Hierdie drie vorme is nie drie dele van sy wederkoms in die sin dat slegs 'n gedeelte van sy koms in elk van die vorme afgehandel word en ons matematies sou kon sê dat twee-derdes van sy wederkoms nou voltooi is nie. Barth sien hier 'n analogie met die triniteit, en wel só ,,dass diese Formen nicht nur in dem einen Ganzen der Aktion zusammengehören, die sich in ihnen allen u.zw. in jeder von ihnen in ihrer Einheit und Ganzheit darstellt - sondern als die Formen dieser einen Aktion auch unter sich dadurch verbunden sind, dass eine jede von ihnen die beiden anderen - sei es antezipierend oder rekapitulierend mitenthalt, dass sie, ohne ihre Besonderheit zu verlieren und ohne die der beiden anderen zu zerstören, auch an ihnen Anteil hat, auch in ihnen wirksam und sichtbar ist. Als der von den Toten Auferweckte ist Jesus Christus virtuell schon auch in der Ausgiessung des Heiligen Geistes, ja schon auch in der Auferweckung aller Toten und im Vollzug des Weltgerichts begriffen. Die Ausgiessung des Heiligen Geistes geschieht offenbar in der Kraft seiner Auferstehung von den Toten, ist aber auch schon sein

\footnotetext{
29. Idem., p. 338. Kursivering van Barth.

29. Idem., p. 339 en telkens later.

30. Idem., p. 339.
} 
Anklopfen als der abschliessend und endgültig Kommende und als solches wirksam und vernehmbar. Und so ist sein endgültiges Kommen zur Totenauferweckung und zum Gericht doch nur die Vollendung dessen, was er schon in seiner Auferstehung angefangen und in der Ausgiesung des Heiligen Geistes fortgesetzt hat"31).

In hierdie lig is dit duidelik hoedat Barth nie net die „letzte Wiederkunft" as die voleinding sien nie, maar die opstanding van Jesus ,schon das grosse Consummatum est!"’2) kan noem, en die kerk (as die werk van Christus deur sy koms in die Heilige Gees) "das eschatologische Faktum par excellence" ${ }^{33}$ ).

In sy allerbreedste lyne is dít dus die eskatologiese ontwerp van Barth: die één wederkoms geskied in drie vorme wat in die tyd uitgesprei is in die verlede (die opstanding), die hede (die uitstorting en teenwoordigheid van die Heilige Gees) en die toekoms (die laaste wederkoms).

Dit is belangrik om te let op die ooreenkoms tussen hierdie finale ontwerp van die eskatologie in sy allerbreedste lyne, en die ewigheid van God wat in K.D. II 1 as Vor-, Uber- en Nachzeitlichkeit gedefinieer is. Ook sy ewigheid is éen ewigheid vanuit drie gesigspunte gesien.

\section{DIE FINALE ONTWERP:}

Tans is dit nodig om hierdie finale ontwerp (één wederkoms in drie gelykwaardige maar ongelyktydige vorme: Jesus se opstanding, sy koms in die Heilige Gees en sy laaste wederkoms) in meer besonderhede te skets. Allereers sal die eskatologiese betekenis van elk van die vorme nagegaan word en dan die sin van die eskatologie as leerstuk wat onderskeie is van die ander loci.

\section{A. DIE ESKATOLOGIESE BETEKENIS VAN DIE OPSTANDING VAN JESUS CHRISTUS:}

Die eiesoortige betekenis van die opstanding van Jesus as een van die vorme van sy Parusie word enigsins duidelik as dit afgegrens word teenoor die betekenis van sy laaste wederkoms.

Hierdie twee gebeurtenisse moet nie absoluut geskei word nie. Alhoewel dit inderdaad vir ons twee gebeurtenisse is, is dit „für ihn ein einziges: seine Auferstehung ebenso die Vorwegnahme seiner Parusie wie seine Parusie der Vollzug und die Erfuillung seiner Auferstehung" ${ }^{34}$ ).

31. Idem.. p. 341.

32. K.D. III 2, p. 586.

3. K.D. IV 3, p. 370 .

34. K.D. III 2, p. 588. 
Tog is daar ook verskil in die eskatologiese betekenis van sy opstanding en sy wederkoms. In sy opstanding is sy koms beperk tot die wat in Hom glo, dit wil sê partikulier en voorlopig, terwyl sy wederkoms volkome, finaal en universeel is ${ }^{35}$ ). In K.D. III 2IV 1 staan sy opstanding en sy wederkoms nog in die verhouding begin-voleinding ${ }^{36}$ ). In K.D. IV 3 kom die gelykwaardigheid van hierdie twee vorme egter sterker na vore. Wat die saak, omvang en gehalte betref, is hierdie vorm nie geringer in waarde as die ander twee nie, maar identies - soseer dat Barth verklaar: „eben im Osterereignis hat ja das Eine, Ganze auch in seinen folgenden Formen seine Ur- und Grundgestalt, so dass man wohl versucht sein Könnte, es als einen einzigen Vollzug eben der Auferstehung zu beschreiben" ${ }^{3 i}$ ). Trouens, alreeds in K.D. III 2 het hy verklaar: „Nichts, was sein wird, was am Ostertag . . . nicht schon geschehen wäre!'”38). Nogtans ontkom Barth nooit geheel aan die skema begin-voleiding as hy die verhouding opstanding-wederkoms moet omskryf nie. Pas nadat hy hulle identiteit beklemtoon het, praat hy tog weer van Jesus se wederkoms as sy „Anwesenheit in ihrer abschliessenden Gestalt"'39), en van sy opstanding as ,die Wiederkunft ... in ihrem Anheben"40).

Om vervolgens die eskatologiese betekenis van die opstanding te begryp, is dit nodig om dit in verband met die dood van Christus te sien. Sy dood en begrafnis is ons einde, ons dood en begrafnis. In sy kruis kruisig en vernietig God die ontroue bondelinge, ontneem $\mathrm{Hy}$ ons-in-ons-afvalligheid ons toekoms, handel Hy finaal af met die ongehoorsame mensdom, voltrek Hy sy vernietigende oordeel oor sy skepping. Hy doen dit egter nie om ons alle toekoms te ontneem nie, maar om ons 'n nuwe toekoms te gee. Hy spreek sy radikale, kritiese NEE in die kruis uit, nie omdat dit die enigste of die belangrikste woord is wat Hy vir ons te sê het nie. Hy oordeel om vry te spreek. Hy sê nee, om ja te sê. Hy kruisig om op te wek. Hy beëindig ons sondige, ontroue bestaan om ons op te wek in 'n nuwe lewe, om ons die wedergeboorte te skenk deur die opstanding van Jesus Christus

35. K.D. IV 1. p. 821. In K.D. III 2. o.a. p. 588 en IV 1. o.a. p. 821, het hy nog die opstanding ook as vorübergehend teenoor die wederkoms afgegrens. omdat sy koms deur die uitstorting van die Heilige Gees tydelik onderbreek is. In K.D. IV 3. sien hy die saak natuurlik anders omdat die uitstorting van die Heilige Gees nou nie meer 'n onderbreking van sy koms is nie, maar die tweede vorm daarvan.

36. K.D. III 2, p. 589.

37. K.D. IV 3. p. 338-9.

39. K.D. III 2, p. 588 .

29. K.D. IV 3, p. 341. Kursivering van my.

40. Idem., p. 347. Kursivering van my. 
uit die dode. (Petr. 1:3). Hy ontneem ons ons gedoemde toekoms om ons 'n ewige, heerlike toekoms te gee. Hy begrawe ons in ons ontrouheid om ons as sy troue bondgenote op te wek.

Jesus se opstanding is dus God se JA vir alle mense (II Kor. 5:19). Ná en op grond van sy opstanding kan God se nee en sy oordeel nooit weer as 'n selfstandige, onafhanklike boodskap verkondig word nie, maar steeds as die oorwonne woord, as die boodskap wat onder die ja van God $\operatorname{staan}^{41}$ ).

Teen hierdie agtergrond sit Barth die eskatologiese betekenis van Christus se opstanding dan breedvoerig uiteen ${ }^{42}$ ).

\section{(1) DIE NOETIESE BETEKENIS:}

Alreeds in die kruis van Christus het die situasie tussen God en die wêreld radikaal en finaal verander. Vergelyk onder andere Ef. 2:15, 16; Kol. 1:20; 2:14, 15. Deur sy opstanding maak God dit egter aan die wêreld bekend. Dit is die noëtiese of openbaringsbetekenis van die opstanding. Jesus se opstanding is die openlike uitspreking van God se groot ja en amen waaraan God so getrou sal bly as aan Homself, sodat alles wat nog op sy opstanding volg, niks meer kan wees nie as net die herhaling, ontvouing en bevestiging van wat alreeds in sy opstanding geopenbaar is ${ }^{43}$ ). Wat in die opstanding gebeur is ,ein göttlich Noëtisches, das als solches die ganze Kraft des göttlich Ontischen hat". In sy opstanding het God bekend gemaak dat Hy finaal vir die mens gehandel het, en deur hierdie bekendmaking het Hy Homself openlik verbind aan hierdie gevalle beslissing vir die mense as met 'n waarborg wat met sy eie hand geskryf en met sy eie seël verseël is. Kortweg: „Neve Schöpfung ist in Jesu Christi Auferstehung geschehen" ${ }^{44}$ ).

\section{(2) DIE TOTALE, UNIVERSELE EN FINALE BETEKENIS.}

As Johannes verklaar dat hulle sy heerlikheid aanskou het (Joh. 1:14), mag ons hieraan geen perke stel nie. Wat hulle in die veertig dae na sy opstanding gesien het, was niks meer of minder as die begin van wat eenmaal voor alle oë openbaar sal word nie. Hulle het naamlik die werk wat $\mathrm{Hy}$ in sy lewe en sterwe volbring het, en sy ganse uitwerking gesien.

Die nuwe verhouding waarin mens en wêreld deur sy kruis tot God staan, word in sy opstanding geopenbaar as 'n totale vernuwing. Dit is nie langer slegs 'n moontlikheid nie. Dit is tans

\footnotetext{
41. Vgl. K.D. IV 1, o.a. p. 378-388.

42. K.D. IV 3, p. $342-366$.

43. Idem., p. 343.

44. Idem., p. 346. Kursivering van Barth.
} 
'n werklikheid, dit het begin. Die mens is alreeds geregverdig en geheilig; sy sonde is alreeds vergewe en vernietig; hy is alreeds kind van God, erfgenaam en deelgenoot van die ewige lewe.

Hierdie nuwe verhouding is ook universeel. Die opstanding van Jesus en God se ja wat daardeur bekend gemaak word, is nie vir die private genot van die apostels nie. Die Opgestanene het aan die dissipels verskyn om aan hulle die sendingbevel te gee. Net soos Christus se kruis die versoening van die wêreld is, is die doel van sy opstanding die wêreldwye sending. Die eersgeboorteplig van die (eerste) gelowiges is hulle sendingplig. „Eine Christenheit ohne Sendung an Alles wäre gar nicht Christenheit"15).

Derdens is die nuwe verhouding finaal, dit wil sê dit is geldig vir die begin en die voortgang en die einde van die wêreld. Wat Pase in die wêreld ingebring het, aan die wêreld meegedeel en ons eie gemaak het, is die lewe in die gemeenskap met God, die ewige lewe. Hierdie lewe het tans 'n voortgang en gaan 'n voleinding tegemoet. In die voortgang en in die voleinding sal dit nie ' $n$ ander gawe wees as wat ons alreeds in die opstanding van Jesus geskenk is nie; omdat daar geen groter, hoër of beter gawe is nie. Wat die wêreld nog kan ervaar, is niks meer as die groei en die vrug van die lewenskiem wat deur die opstanding van Jesus in hom ingeplant is nie. Die vorm van die gawe kan dus verander (net soos die vorm van die wederkoms verander naamlik in die uitstorting van die Heilige Gees en in die laaste wederkoms), maar nie die gawe sélf nie (soos trouens ook nie die koms van Christus self nie).

\section{(3) DIE VREEMDHEID OF NUUTHEID VAN SY OPSTANDING:}

As Jesus Christus opstaan uit die dood, is dit dieselfde Christus wat tevore gekom het en gesterf het, maar sy nuwe koms is nie bloot 'n verlengstuk van vroeëre lewe nie. Die is naamlik in sy dood werklik afgesluit en alleen maar verlede tyd. Die lewe van die kosmos berg nie in sigself die moontlikheid om nadat dit verby is, weer voortgesit te word nie. Gevolglik kan 'n skepsel na sy dood alleen voortleef as hy van God nuwe lewe as 'n geskenk ontvang, Jesus se opstanding beteken dus dat Hy van 'n plek af (terug-) gekom het vanwaar niemand nog teruggekom het nie. Hier is geen blote verskyning op die spel nie - ook nie maar net 'n herinnering nie. Die werklike, liggaamlike ontmoeting van Jesus met sy dissipels is die enigste moontlike

43. Idem., p. 351 . 
verklaring van die oorwinning van hulle ongeloof en ook die enigste grond vir die bestaan van Nuwe Testamentiese geloof, boodskap en gemeente.

Hierdie „schlechtinige(n) Neuheit der Gestalt, in der Jesus Christus sich selbst ... in der Osteroffenbarung der Welt und uns mitteilt"46) is ook die rede waarom Jesus se opstanding so mities voorkom dat dit glad nie in enige wêreldbeeld inpas nie ${ }^{4 i}$ ). Netsoos in die geval van die bestaan van God, moet elke poging om Jesus se opstanding in enige wêreldbeeld in te pas, noodwendig op die loëning van sy opstanding uitloop omdat ons in die opstanding van Jesus die doel, einde en heilstoekoms van die wêreld alreeds in die hede aanskou. Hier is die mens se verlossing as die verewiging van sy tydelike lewe, ,,als Verjenseitigung ihres diesseitigen Lebens, als Uberkleiding . . . ihrer Menschlichkeit mit seiner, der göttlichen Herrlichkeit, Vollendung seiner Schöpfung durch die neue Schöpfung . . . " $\$ 8$ ). In hierdie sin is Pase die laaste uur, alreeds die einde van die wêreld, alreeds die begin van sy nuwe lewe in die nuwe, ewige gestalte wat God hom geskenk het.

Terwyl die probleem van die onsigbaarheid en weerspreeklikheid van dit alles onder die eskatologiese betekenis van Jesus se koms in die Heilige Gees behandel sal word, moet tans net opsommend vasgestel word wat die eksatologiese betekenis van die opstanding van Jesus Christus vir die wêreld is: ${ }^{49}$ ) In die opstanding as die verskyning van die mens Jesus in die heerlikheid van God het die wêreld sy toekoms, doel en einde bereik as die wêreld wat in Christus met God versoen is, dit wil sê die wêreld se heilstoekoms het werklikheid geword as 'n konkreet-reële element van sy bestaan. Dit beteken dat die wêreld nie meer 'n verlore wêreld is nie. Dit kan met die wêreld in die toekoms nie gaan soos dit in die verlede gegaan het nie. Sy toekoms sal ooreenstem met die feit dat hy versoen is, naamlik verlossing uit die dood, verlossing as verewiging van sy tydelike lewe en as „Verjenseitigung ihres diesseitigen Lebens”. Immers in Jesus as die Opgestanene is die lewe van die ganse skepping, ja van alle mense alreeds geopenbaar as die lewe wat alreeds verewig en in die "Jenseits" opgeneem is. Die toekoms wat vir die wêreld gewaarborg is in die versoening, het in die opstanding van Christus konkreet, reëel teenwoordig geword. Die opstanding van Jesus is alreeds die laaste uur van die wêreld se "bisherige" gestalte en ook alreeds die eerste uur van sy nuwe gestalte. „Es

\footnotetext{
46. Idem., p. 355.

47. Idem., p. $357 \mathrm{v}$. en $361 \mathrm{v}$.

43. Idem., p. 363.

49. Idem., p. 363v.
} 
war, was am Ostertage geschehen, schon das Ende Weltseins, des Seins des Menschen in seiner bisherigen, seiner Todegestalt und schon der Anfang seines Seins in der ihm von Gott geschenkten neuen, ewigen Lebensgestalt" ${ }^{50}$ ).

Dit is dan die eskatologiese betekenis van die opstanding van Jesus Christus volgens Barth. En in hierdie lig is dit duidelik hoedat hy Jesus se opstanding een van die vorme van die Parusie kan noem, 'n vorm wat gelykwaardig is aan altwee die ander. Dit is ook duidelik hoedat hy kan sê dat ons nie nog iets anders, 'n ander gawe kan verwag as wat reeds gegee is in die opstanding van Jesus nie. Die vorm mag verander, net soos die Parusie self ook nog twee ander vorme sal aanneem, maar die gawe self is reeds gegee, die einde is reeds bereik. Wat nog kan, kan slegs 'n bevestiging, herhaling en uitbouing wees van die einde wat alreeds in die opstanding van Jesus bereik is.

Inderdaad is die opstanding van Jesus dan ,schon das grosse Consummatum est!"'51).

\section{B. DIE ESKATOLOGIESE BETEKENIS VAN DIE TUSSENTYD:}

Die brandende vraag waarvoor die radikale eskatologiese betekenis van die opstanding van Jesus Christus mens stel, is nou dit: „Wie war es möglich, dass ihre dort, in jenem Ereignis Gegenwart gewordene Zukunft nicht von dort aus sofort wie eine Sturzwelle über die ganze Welt ging, alle Menchen aller Zeiten und Räume - aben ihre Zukunft war doch dort, in der Erscheinung der auferstandenen Jesus Christus Gegewart geworden! - mit ihrer Gegewart erfüllte?'"52). Anders gestel: hoe is dit moontlik dat die doel wat God met die wêreld bereik het, die heilstoekoms van die wêreld wat alreeds in Jesus se opstanding aangebreek het, skynbaar tot vandag toe tot Jesus beperk bly, en die wêreldgeskiedenis skynbaar voortgaan asof niks gebeur het nie?

Hierdie vraag gee Barth die geleentheid om die eweneens radikale eskatologiese betekenis van die koms van die Heilige Gees as die tweede vorm van die Parusie van Jesus Christus uit te werk. Alhoewel die opstanding van Jesus Christus alreeds "consummatum est", is die nie die enigste vorm van die voleinding nie. Dit is nie minder of meer belangrik nie as die tweede vorm van die Parusie naamlik die koms van Jesus Christus in die uitstorting van die Heilige Gees.

50. Idem., p. 364 .

51. K.D. III 2, p. 586

52. K.D. IV 3, p. 365. 
Barth se volledige antwoord op hierdie vraag, naamlik waarom die consummatum est in die tussentyd skynbaar tot Jesus alleen beperk bly, word gegee in die vorm van 'n driedelige voorlopige en 'n finale antwoord.

\section{(1) DIE VOORLOPIGE ANTWOORD:}

(a) Die afwesigheid van ons heilstoekoms is SKYN:

Inderdaad het die laaste en die eerste uur in Jesus se opstanding geslaan. Inderdaad het ons heilstoekoms toe aangebreek. Nie net die versoening nie, maar ook die verlossing en die voleinding van die wêreld het daar in sy volle omvang en diepte plaasgevind. „Vermöchten wir mit den Augen Gottes zu sehen, so würden wir dessen gewahr sein, dass dem Schein zuwider, in Wirklichkeit alles schon anders, schon neu geworden, schon zurecht und in Ordnung gebracht ist. Nur dass wir sie so nun eben nicht zu sehen vermögen!" ${ }^{33}$ ). Immers ons leef tans in geloof, nie in aanskoue nie, en ons lewe is met Christus verborge in God. 2 Kor. 5:7 en Kol. 3:3.

Tog bly die vraag in die vorm: waarom is ons nuwe lewe en die voleinding tans nog verborge en nie sigbaar, tasbaar en ervaarbaar nie?

(b) Die openbaring van ons heilstoekoms het tans nog net BEGIN:

Ons mag nie verwar word deur die feit dat ons in Pase net met die begin van die openbaring van ons verlossing en die voleinding van die wêreld te doene het nie. Die finale, volledige openbaring van die heil vind plaas by die wederkoms. Die opstanding van Christus is immers nog net die eerste - nog nie die laaste en beslissende vorm van die Parusie nie. Ons heilstoekoms, wat in sy opstanding alreeds werklikheid geword het, het daarmee nog nie opgehou om ons toekoms te wees nie. Ons wag nog in hoop en geduld. Ons is tans nog onderweg maar ons kan dit verduur omdat ons onderweg is (naamlik die opstanding van Jesus) na die finale vorm waarin dit tans nog nie werklik is nie maar by die laaste wederkoms werklik sal word.

Tog bly die vraag waarom ons heilstoekoms tans nog alleen in Christus werklik is en elders nog toekoms bly; waarom Pase nog net die begin is en nog nie „das Ganzes dieses Geschehens sein"? $\left.{ }^{54}\right)$. Wat is tog die sin van die feit dat Christus nie met sy opstanding só weergekom het dat alle verdere wederkoms oorbodig sou wees nie? Waarom is ons en alle ander skepsele nog nie tuis nie?

53. Idem., p. 366 .

st. Idem., p. 368 . 
(c) Verkondiging, geloof en kørk is tog alreeds sigbare voleinding

Ons loop naamlik gevaar om te vergeet wat die opstanding van Jesus alreeds sigbaar in die lewens van ontelbare mense bereik het en steeds weer bereik. Wat van byvoorbeeld die teenwoordigheid van ons heilstoekoms in die verkondiging van die lewende Heer? Gaan die wederkoms van Christus nie voort in die dubbele gebeure van christelike kerugma en christelike geloof, en veral in die versameling en opbouing van die christelike gemeente nie? Is die kerk nie in sy bestaan en in sy doen en late 'n antisipasie op die toekomstige volle verlossing en voleinding nie? „Ist sie, die Kirche, nicht das eschatologische Faktum per excellence" nie? ${ }^{35}$ ).

Tog is dit sondermeer duidelik dat met hierdie driedelige voorlopige antwoord - wat inderdaad sy eie legitimiteit en waarde het - die vraag nog nie tot swye gebring is nie. Immers ook die kerk is 'n uiters gebrekkige eskatologiese werklikheid. Hoeveel maet ons nie verswyg en toesmeer, en hoeveel aan die ander kant nie aandik en opblaas om in die kerk 'n realisering van ons heilstoekoms te sien nie? Sal die Christendom en die kerk in hierdie bedeling ooit meer wees as die plek vanwaar die mense kan roep en bid: „Here, erbarm U oor ons; Amen, ja kom, Here Jesus"? Kan die tyd van die kerk méēr wees as adventstyd?

\section{(2) Die finale antwoord:}

Dit is noodsaaklik om net eers weer die vraag wat beantwoord moet word, noukeurig onder oë te kry: Hoe is dit moontlik (en wat is die sin daarvan) dat Jesus se opstanding wat inderdaad 'n vorm van die voleinding is, nie die voleinding in elke vorm is nie, maar dat ons heilstoekoms nog slegs in Hom 'n volkome geopenbaarde werklikheid is, terwyl die wêreldgeskiedenis skynbaar voortgaan asof niks beslissends gebeur het nie?

Die uitgangspunt om hierdie vraag te beantwoord, is dat nie net die vraag nie maar ook die antwoord van Jesus Christus af kom. Die volle openbaring van die heilstoekoms is nog uitstaande omdat God dit so wil - as 'n sinvolle, goeie ordening van God wat ons eenvoudig moet aanvaar en waaroor ons moet bly wees. Jesus Christus is nog op pad. As openbaarder het $\mathbf{H y}$ nog nie sy werk beëindig en sy doel bereik nie. Hy is nog besig om bekend te maak dat die heilstoekoms wat alreeds in Hom werklik is, die heilstoekoms van die hele werreld is en dat sy heerlikheid ook die heerlikheid is van die wêreld wat met Hom versoen is. In Hom is die heilstoekoms van die wêreld alreeds

5.) Idem.. p. 370. 
werklik. In die wêreld moet dit nog verwerklik word. Ons kan gevolglik niks anders en niks beters doen nie as om Hom op hierdie weg te vergesêl.

Primêr is Hy nog op pad en daarom ons met Hom. Dit is nie allereers die wêreld of die kerk of die enkele Christen wat nog op pad is, wat nog ly, wat nog stry, wat nog nie die oorwinning finaal behaal het, wat nog sug en nog nie die doel bereik het nie. Allereers is dit $\mathbf{H y}$. $\mathbf{H y}$ as die Hoof van die kerk en kosmos, Hy as die Eersteling van die ganse skepping is nog die stryder en die pelgrim. Dit is sy wil dat die begin en die einde van sy werk nie saamval nie maar dat $\mathrm{Hy}$ van die begin van die openbaring van ons heilstoekoms (wat alreeds in en deur sy opstanding werklik is) moet voortgaan na die voleinding daarvan. Vir ons is daar net een sinvolle reaksie: om aan die volvoering van hierdie goeie wil van Jesus Christus deel te neem; die weg wat Hy nog wil gaan, met Hom saam te gaan; die stryd wat Hy nog wil stry, saam met Hom te stry; in kort: Hom na te volg ${ }^{56}$ ).

Ook hiermee is die „waarom" egter nog nie stilgemaak nie. Natuurlik sou dit ook moontlik kon wees dat hierdie ordening van God en hierdie wil van Christus blymoedig aanvaar word as sy goeie ordening en wil net omdat dit sy ordening en wil is. Maar in hierdie geval is dit tog moontlik om uit die doel van die skepping te begryp waarom hierdie wil goed is en waarom ons bly mag wees dat Christus hierdie afstand tussen die eerste en die derde vorm van sy Parusie geskep het. Van ewigheid af is Christus naamlik nie eensaam nie; dit wil sê nie alleen die verkorene van God nie. Die skepsele is in Hom God se verkorenes. En daarom wil Christus God se doel nie sonder ons bereik nie. In die tyd wat die eerste en die derde vorme van sy Parusie skei, wil Hy ons die geleentheid bied om nie net toeskouers by die oes te wees nie, maar deel te neem aan die insameling. Immers God wou nooit die mens slegs 'n voorwerp van sy handelinge laat wees nie, maar sy vrye skepsel. Die sin van die tussentyd is dus dat ons aan sy werk mag meedoen. Hy wil deur sy gemeente in die wêreld aangeroep en verkondig word. Hy bied ons die geleentheid om in sy diens te tree. Dít is die sin van die tussentyd. En dit is genade. Want hoe groot die weldaad ook sou wees wat $\mathrm{Hy}$ ons bewys het as $\mathrm{Hy}$ sy opstanding en sy laaste wederkoms laat saamval het, sou dit tog 'n ongenadige weldaad gewees het, 'n guns waarin ons geen geleentheid sou hê om werklik sy bondgenote te wees en so sy oorspronklike skeppings-

56. Idem., p. 375-381. 
doel te bereik nie ${ }^{57}$ ). Hy handel egter nie eenvoudig oor ons koppe heen nie. Hy verag nie ons lof en dank nie, maar begeer dit en bied in hierdie tussentyd - as die tyd van sy Parusie in die Heilige Gees - aan ons die geleentheid om Hom met ons eie vrye werk na te volg en so sy skeppingsdoel (naamlik die verbond waarin Hy onse God en ons sy troue bondgenote is) te bereik. Hierin - en dus in die tussentyd - sien ons opnuut God se neerbuiging na ons en sy trou teenoor ons as sy bondgenote ${ }^{58}$ ).

Die allebelangrikste aspek van die eskatologiese betekenis van die tussentyd moet tenslotte herbeklemtoon word. In hierdie tyd waarin die gemeente die geleentheid het om Jesus as God se troue bondgenote na te volg, het ons die Here agter ons (in die eerste vorm van sy Parusie) en voor ons (in die laaste vorm, naamlik sy wederkoms). Maar is Hy tans afwesig? Moet die Christene tans as die vicarii Christi optree? En die wêreld wat tot geloof moet kom, is hulle hiervoor van die afwesige Christus se plaasvervangers afhanklik, naamlik van die duidelikheid, oortuigingskrag en geloofswaardigheid van die kerk se boodskap? Is die Christene dus in die tussentyd op hulleself - en die wêreld op die Christene - aangewese? Is Christus se Parusie tans onderbreek om later voortgesit en voltooi te word? ${ }^{59}$ ).

Op al hierdie vrae is die antwoord beslis nee. Die versoende wêreld kry tans die geleentheid om Christus na te volg terwyl Hy deur die wêreld op pad is van die eerste na die laaste vorm van sy Parusie. Hy is almal se hoop. Hy het geen verteenwoordigers op aarde nodig nie. Hy doen sélf sy werk. Sy Parusie is nie onderbreek om Jater weer hervat te word nie. Tussen die eerste vorm en die laaste vorm lê die tweede vorm: sy koms en teenwoordigheid in die Heilige Gees. Die Heilige Gees is sy direkte onmiddellike teenwoordigheid en werking onder, by en in ons ${ }^{60}$ ). Ons leef dus nie in die tussentyd in 'n tyd van onderbreking en stilstand - of in 'n tyd waarin ons die dinge aan die gang moet hou nie. In die Heilige Gees het Christus gekom en is Hy op weg deur die wêreld. Sy koms in die Heilige Gees is net so wesenlik in sy Parusie as wat sy opstanding en sy laaste wederkoms dit sal wees. Ons wag nie tans op 'n afwesige Christus

57. Vir die verbond as die inwendige grond (of doel) van die skepping, en die skepping as die uitwendige grond (of ruimte) vir die verbond, vgl. o.a. K.D. III 1. par. 41.2 en 3. Op p. 106 v. lees ons bv.: ..So ist der Bund das Ziel der Schöpfung, die Schöpfung der Weg zum Bunde ... . Der innere Grund des Bundes ist Gottes freie Liebe ganz allein . . . Die Schöpfung ist der äussere und nur der äussere Grund des Bundes, man darf wohl sagen: seine technische Ermöglichung, die Bereitstellung und die Ausstattung des Raumes, in welchem die $\mathrm{Be}$ gründung und Geschichte des Bundes sich abspielen".

58. K.D. IV 3, p. 382-386.

59. Só het Barth dit trouens nog in K.D. II I-IV 1 gestel.

60. K.D. IV 3, p. 405. 
nie. Terwyl ons sy koms in een vorm (naamlik in die Heilige Gees) beleef, wag ons op sy koms in 'n ander vorm (naamlik sy finale wederkoms). Ons loop nie tans alleen op pad na Hom toe nie, ons loop agter Hom aan op pad na sy finale doel: sy wederkoms.

In hierdie tweede vorm van sy Parusie is Christus eerstens nic minder werklik tecnwoordig as in die eerste en derde vorme nie. Dit is sy eie, onmiddellike, persoonlike koms, sy Parusie, teenwoordigheid en selfopenbaring. Die feit dat $\mathrm{Hy}$ in die hemel, dit is in die verborgenheid van God ingegaan het, beteken nie dat sy teenwoordigheid tot daardie sfeer beperk is en Hy verhinder is om onder ons te wees, te werk en Homself te openbaar nie.

In hierdie tweede vorm van sy Parusie is Christus tweedens nie anders as in sy eerste en laaste koms nie. Hy wat tans by ons is, is dieselfde een wat tevore reeds gekom het. Hy is tans nie slegs na sy Godheid (,,als ein reines Gottwesen"' 1 ) by ons teenwoordig soos vraag 47 van die Heidelbergse Kategismus leer nie. Sedert die skeiding tussen God en mens in die inkarnasie opgehef is, word dit nooit weer herstel nie. Hy het in die eenheid van sy goddelike en menslike bestaan opgestaan, en ter hemel gevaar - en só sal Hy weer verskyn in sy wederkoms. Só en nie anders nie, het Hy ook in die Heilige Gees gekom: as ware God en ware mens. Hoe sou Hy buite sy aangenome vlees alle mense se hoop kon wees?

Hierdie tweede vorm van sy Parusic is derdens nie kwalitatief geringer as die eerste en die derde vorm nie. Daar is nie ' $n$ ander vorm van sy Parusie wat goddeliker, heerliker en heilsamer sal wees nie. Indien die indruk bestaan dat sy teenwoordigheid in die Heilige Gees geringer, minder hulpryk en selfs onbevredigend is, is dit aan ons te wyte - nie aan Hom nie. „Die Vorstellung von ihr (naamlik die tussentyd) als einem Vakuum muss bis zum letzten Rest verschwinden"62). Die tussentyd is nie „maar net" die tyd van die Heilige Gees nie! Wat sou "maar net" in hierdie verband beteken? "Gott war nicht nur in alter Zeit herrlich und wird es nicht erst in der letzten Erfülung seiner Verheissung werden: er ist es schon jetzt und hier in der Verheissung seines Geistes - indem er selbst in ihr gegenwärtig und am Werk ist, auch gestern, heute und morgen. In Blick auf ihn bestecht aller Anlass, gerade unsere Gegenwart nicht zu bedauern, nicht zu beklagen, sondern zu loben, zu ihr nicht Nein, sondern von Herzen Ja zu sagen" ${ }^{63}$ ).

\footnotetext{
61. K.D. IV 3. n. 413.

62. Idem., p. 415 .

63. Idem., p. 415 ,
} 
In kort is die eskatologiese betekenis van die tussentyd dus die feit dat dit die tweede vorm van die Parusie van Jesus Christus is, ' $n$ vorm wat in geen opsig minderwaardig of minder heerlik of minder belangrik as die ander twee vorme is nie. Die sin van hierdie koms en teenwoordigheid is dat God in sy genade aan ons die geleentheid gun om nie net toeskouers van sy oes te wees nie, maar mee te doen en só meer as net voorwerpe van sy handelinge te wees, maar dit te word waarvoor Hy ons bestem het: sy troue bondgenote. Die tussentyd is die tyd waarin ons Jesus kan navolg terwyl $\mathbf{H y}$ op pad is deur die wêreld: op pad van sy opstanding na sy laaste wederkoms.

\section{DIE ESKATOLOGIESE BETEKENIS VAN SY WEDERKOMS: 1. 'N EIE OPMERKING:}

Eers wanneer ons oor die wederkoms moet handel, kom ons voor Barth se eskatologie as 'n onvoltooide simfonie te staan. Aan die een kant beteken die feit dat ons nou eers die vakuum in sy eskatologie bereik, 'n bevestiging van sy uitspraak in die voorwoord tot die Fragment dat hy (indirek én direk) meer eskatologie geskryf het as wat gewoonlik aanvaar word! Minstens die lengte van hierdie referaat moet ons al daarvan oortuig! Aan die ander kant is dit egter ewe waar dat hierdie ontbrekende deel 'n wesenlike vakuum is. Want God se doel word (soos Barth trouens self oor en oor verklaar het) eers ten volle en in sy finale vorm bereik by die wederkoms van Christus. Eers as ons weet wat dit inhou, sal ons finaal en verantwoord oor Barth se eskatologie kan oordeel. Om twee redes is dit tans egter vir ons onmoontlik: omdat Barth op 10 Desember 1968 heengegaan het sonder om die derde vorm van die Parusie volledig uit te werk, én omdat hy in elk geval nie geweet het „wat ons sal wees nie" (1 Joh. 3:2). Hierdie uitspraak behoort ons dogmatici te noop om meer terughoudend en spaarsaam oor die finale vorm van die Parusie en oor die voleinding te skryf as wat dikwels (óók in die Gereformeerde teologie) die geval is. Die kenmerkend vrye manier waarop Ou Testamentiese beloftes in die Nuwe Testament vervul is (vgl. onder andere Joël 2:28-32 wat volgens Hand. 2:16v. op Pinksterdag op 'n besonder ,onletterlike" wyse vervul is en in werklikheid 'n veel heerliker, dieper en ruimer betekenis gekry het as wat deur die suiwerste wetenskaplike eksegese alleen uit Joël 2:28-32 af te lei was), moet ons leer om met die beloftes wat nog vervul moet word by die wederkoms van Christus nie al te letterlik om te gaan asof ons presies weet hoe die vervulde werklikheid daar sal uitsien nie. Hoeveel kritiek daar ookal uitgeoefen word op die aanhaling van 1 Kor. 2:9 in vraag 58 van die Heidelbergse Kategismus, tog bly 
die belangrike betekenis van hierdie aanhaling juis in die antwoord oor die ewige lewe dat die legitieme Gereformeerde tradisie ' $n$ begrip het van die vryheid van God in die vervulling van sy beloftes. Hulle wou God nooit bind aan 'n letterlike „uitkom" van voorspellings - wat trouens 'n heidense karikatuur van die Bybelse vervulling van beloftes of profesië is nie. God is oneindig groter as sy beloftes. Hy is vry om ons grondig te verras in die vervulling van die beloftes waarop die kerk nog wag. Die legitieme Gereformeerde teologie het gevolglik altyd oorvloedig geskryf oor die beloftes wat alreeds vervul is, en spaarsaamlik oor die wat nog nie - of nog nie volledig - vervul is nie.

In hierdie lig mag dit van profetiese betekenis wees dat Barth wél breedvoerig gehandel het oor die beloftes wat alreeds vervul is, naamlik die eerste en tweede vorme van die Parusie (dit is Jesus se opstanding en sy koms in die Heilige Gees) maar nie - of in elk geval uiters indirek en sporadies - oor dié vorm van die Parusie wat nog nét belofte is en waarvan die kerk nog die vervulling verwag nie.

\section{DIE CHRISTELIKE HOOP:}

Die enkele aanduidinge wat Barth ons wel gegee het oor hoe hy die derde en finale vorm van die Parusie sien, naamlik die „letzte Wiederkunft" van Christus en die daarmee gepaardgaande voleinding, tref ons hoofsaaklik aan in die gedeeltes waarin hy handel oor die Christelike hoop.

\section{(a) Die voorwerp van ons hoop::}

Wanneer Barth in K.D. IV 3 par. 73, 1 en 2, handel oor die hoop, lui die opskrif van die eerste deel: „Der Erhoffte und die Hoffnung". Hy begin by die Een op wie ons hoop omdat die ganse sin, waarde en krag van ons hoop volkome van Hom afhanklik is. Die feit dat ons hoop, het géén waarde as ons hoop nie op Hóm gerig is nie, net soos die feit dat ons glo, geen waarde het as ons nie in Hóm glo nie. Nog die waarde van ons geloof nóg die waarde van ons hoop het opsigself enige betekenis. Ons hoop ontleen sy volle betekenis aan die feit dat Christus 'n toekoms het. Ons gaan die voltooiing van sy openbaring tegemoet. Netsoos ons tans nog op pad is omdat $\mathbf{H y}$ nog op pad is, mag en moet ons hoop dat ons ons doel (dit is God se doel met ons) sal bereik omdat Hy sy doel sal bereik. Daarom verwag ons ook nie allereers bepaalde ,laaste dinge" nie, ons verwag Hom, en deur Hom sal ons volle erfenis geopenbaar word. 
Volgens Barth het die eerste Christelike gemeentes op Christus gehoop; hulle het sy koms in heerlikheid (wat in sy opstanding begin het en in sy wederkoms voltooi word) verwag. Hulle het nie gehoop op die verkryging van allerlei abstrakte dinge: die opstanding uit die dode, die vryspraak in die gerig, die ewige lewe, die krone, palmtakke of wit klere nie. Ook nie op die glans van die nuwe hemel of die nuwe aarde, of welke geestelike, morele of fisiese toestande van die komende Godsryk nie. „Oder vielmehr: sie hofft auf das Alles ganz allein darum und damit das sie auf Jesus selber hofft . . Es sind also das Alles nur Prädikate, Annexe, Begleiterscheinungen seiner Erscheinung" ${ }^{(4)}$ ).

(b) Die inhoud van ons hoop:

(i) Die aard van die wederkoms:

Om enigsins te begryp wat ons verwag as ons Christus verwag, moet ons nagaan in watter verhouding die derde vorm van sy Parusie tot die eerste twee vorme staan.

Barth beklemtoon die feit dat ons nie die eerste twee vorme van Christus se Parusie kan aanvaar maar die derde vorm ontken nie $\left.^{65}\right)$. Die Nuwe Testament ken nie 'n geleidelike ontwikkeling vanuit die eerste twee vorme na ' $n$ min of meer ideale toestand op hierdie onvernieude aarde nie. Die wederkoms van Christus is (soos die eerste twee vorme van sy Parusie) onafhanklik van enige kreatuurlike - ook Christelike! — ontwikkeling. Daarom is sy wederkoms ook nie slegs 'n uitwerking en ontwikkeling van wat $\mathrm{Hy}$ in sy opstanding was en in sy teenwoordigheid in die Heilige Gees is nie, maar nogeens 'n nuwe vorm van sy koms.

Verder bring juis die eerste twee vorme van sy Parusie noodwendig die verwagting van die derde vorm mee. Want die bepaalde "nog nie" en beperking wat sy opstanding kenmerk, naamlik dat die einde en die volle heerlikheid nog net in Hom sigbaar en tasbaar bereik is, is in sigself die belofte vir "die Herrlichkeit Jesus Christi auch für die Seinen, das ihnen bestimmt. Erbe, die neue Schöpfung" $\left.{ }^{6}\right)$. Elders lees mens: „Noch hat eben die Zukunft ... damit, das sie in Jesu Christi Auferstehung schon gegenwart wurde, . . . nicht aufgehört, uns . . . Zukunft zu sein" $"$ ). Dit wat in die opstanding begin en in die tussentyd voortgesit word, moet beëindig en voltooi word - en daarvoor kom Christus op die derde wyse, naamlik sy wederkoms.

Aan die een kant sê Barth met veel klem dat die laaste vorm van die Parusie nie anders as die eerste vorm kan wees nie, dit wil sê dat ons nie 'n ander gawe kan verwag nie, maar slegs die

\footnotetext{
6.4. K.D. III 2, p. 589. Vgl. ook K.D. IV 3, p. 1048-1051.

65. K.D. III 2. p. $584 \mathrm{v}$.

fi. Idem., p. $\mathbf{5 8 6}$.

c\%. K.D. IV 3, p. 367 .
} 
bevestiging en uitbouing, herhaling en vernuwing van wat alreeds gegee is in sy opstanding. Aan die begin van IIA is reeds breedvoeriger oor hierdie verhouding gehandel en is gekonkludeer dat Barth enersyds die volkome gelykwaardigheid van die eerste (en tweede) en derde vorme beklemtoon $;$ ). Aan die ander kant (en dit is ook toe reeds aangetoon) praat hy tog van die eerste as die begin teenoor die derde as die voleinding, of van eersgenoemde as partikulier en laasgenoemde as universeel; eersgenoemde as die begin van dit wat in laasgenoemde sy doel bereik; van eersgenoemde as antisipasie op laasgenoemde en laasgenoemde as voltrekking, vervulling en rekapitulasie van eersgenoemde. Daarom is dit ook nie vreemd dat hy andersyds die groot onderskeid tussen hierdie twee vorme kan leer nie. Dán, by sy wederkoms, sal die openbaring van sy heerskappy volkome wees; dán sal $\mathrm{Hy}$, die lig van die lewe, die laaste hoekie van die kosmos deurdring en verlig; én sal die sterflike met onverganklikheid beklee word. Terwyl sy opstandingsheerlikheid sigbaar en tasbaar was vir sy dissipels, is dit tans nog nie geopenbaar wat ons sal wees as Hy verskyn nie (1 Joh. 3:2) ${ }^{69}$ ). Barth kan selfs praat van ,die noch ausstekende Erlösung der in ihm versöhnten Welt" "“").

Die verhouding tussen die tweede en derde vorm van die Parusie word op dieselfde dualistiese wyse omskryf: enersyds geld van Jesus se koms in die Heilige Gees dat daar geen ander vorm van sy Parusie is wat goddeliker, heerliker, heilsamer en van hoër waarde is nie. Inderdaad ,,ist der Welt auch in ihr (naamlik in die tweede vorm, net soos in die eerste vorm) schon Alles gegeben"'1), terwyl hy andersyds ook volkome bewus is van die smart en ellende wat ons in hierdie tyd nog ly - waarvan Christus goddank weet! - en van die feit dat Christus self nog nie ,am Ziel” is nie en nog ly in die tussentyd ${ }^{\text {iz }}$. Daarom kan hy ook van die tussentyd as die ,kleine, vorletzte Zusage" teenoor die wederkoms as die ,grosse, letzte Zusage" praat ${ }^{73}$ ).

Hierdie verhouding sal noodwendig vloeiend bly en nie noukeurig omskryf kan word nie, enersyds omdat ons ,,nog nie weet wat ons sal wees nie" (1 Joh. 3:2) (dit wil sê uit die aard van die onderwerp wat behandel word) en andersyds omdat Barth nooit selfstandig en volledig oor die aard van die derde vorm geskryf het nie.

\footnotetext{
62. K.ก. IV 3. n. 344-348 beklemtoon dic ,alreeds" van die totale en radikale vernuwing.

is. Idem., p. 36R.

io. Idem., p. 396 .

i1. Idem., p. 414

:2. Idem., p. 418-420; Oor cy lyding in die tussentyd: p. 379-380.

73. Idem., p. 415-6.
} 
Tog kan ons samevattend dit sê: Die wederkoms is die volle openbaring van die heerlikheid van God in Christus én van die doel wat God vir ons gestel het en wel universeel (alle ore sal dit hoor en alle oë sal dit sien, Openb. 1:7), direk en sonder teenspraak (elke knie sal buig en elke tong bely, Fil. 2:10-11) en finaal afgeslote - sonder dat daar'n vierde vorm van die Parusie sal wees (dan is God alles in almal, 1 Kor. 15:28).

\section{(ii) Die ewige lewe:}

Barth sien die ingrype van God in die geskiedenis van die mensheid as teleologies gerig. Ons regverdiging en heiliging het 'n doel, en hierdie doel vat Barth saam onder die term ,die ewige lewe"' $)$. Die ewige lewe beteken 'n diepte van gemeenskap met God wat eers in die toekoms vir ons geopen sal word. Hierdie ewige lewe is geen passiewe genot, geen lewelose, dadelose, geskiedenislose bestaan nie, maar omdat God die God van aksie, daad en geskiedenis is, sal ons ewige gemeenskap met Hom, met sy wese ooreenstem. Hierdie aktiwiteit sal die karakter van diens vertoon omdat God ewig Koning bly ${ }^{75}$ ). Hierdie diens sal die karakter van synergisme vertoon. Hier - maar ook nét hier - vind Barth die woord op sy plek. Dit is nie ons verlede of ons hede nie, maar dit is ons toekoms by God: samewerking met God. Maar dan só dat ons nie ons posisie onder God verloor nie. Deur die ewige lewe - wat God alleen besit - uit sy hand te ontvang, word ons nie vergoddelik nie en word die verskil tussen Skepper en skepsel nie opgehef nie. Maar ons sal wel saam met God voel, wil en doen. Ons sal 'n vrye medeverantwoordelikheid vir God se saak aanvaar.

Onsterflikheid en allerlei ander toekomsdrome sou die mens nog self kon uitdink - maar hierdie verhewe doel en heerlike toekoms saam met God is meer as wat ons kon bid of dink of verwag!

Omdat Jesus Christus egter vir ons die ewig lewende Mens is, is die (ons!) ewige lewe dus alreeds teenwoordig in Hom en kry ons in Hom hier en nou daaraan deel. So leef die Christen dus nie net met die oog op die verre toekoms nie, maar ook met die oog op God se toekoms vir ons hier en nou. „Verheissene Zukunft ist ja nicht nur die des Tage des Herrn am Ende aller Tage, sondern gerade weil dieser das Ende und Ziel aller Tage ist, auch die nächste des heutigen und morgigen Tages".

i4. K D. IV 1. p. 119-132.

is. Idem., p. 126. 
(iii) Ons hoop vir die wêreld:

Barth het hom radikaal gestel teen elke vorm van private christen-wees $\left.{ }^{i 6}\right)$. Die saligheid van die enkeling is nie 'n doel in sigself wat in afsondering geniet kan word nie. Trouens die enkele mens word ook nie opsig self gered nie, maar in die breëre samehang waarin God in Christus die wêreld met Homself versoen het en die ganse geskape werklikheid versoen is in die kruis van Christus. Daarom is ook die christelike hoop allermins op die salige toekoms van die individu of selfs van die kerk gerig. Dit gaan om die Koninkryk van God en die enkeling kry as deel van die versoende wêreld aan die koninkryk deel.

Die triomf by die wederkoms sal gevolglik ook 'n totale, universele triomf wees. Die oë van alle mense sal die lig dan sien en verskrik wees, maar hulle ook mag verbly, want alle weerstand word dan gebreek, elke knie buig dan en elke tong bely dat Jesus die Here is.

In hierdie lig is dit nie die taak van die gelowiges om te spekuleer oor wie of hoeveel verlore kan gaan nie, maar om die goeie nuus te verkondig dat die wêreld met God versoen is en dat die toekoms van die wêreld dus ten enemaal nie meer hopeloos kan wees nie, maar radikaal en finaal in 'n nuwe lig (die lig van die wêreld!) te staan gekom het ${ }^{i \pi}$ ).

Om vandag met misplaaste erns oor die moontlikheid van ewige rampsaligheid van bepaalde mense na te dink en môre met eweseer misplaaste heftigheid oor die uiteindelike saligheid van alle mense, is dus een ding - 'n ander ding is dit (en dit is die opdrag van die christelike gemeente) om te weet dat jy verplig is om deur jou christelike woord en daad Jesus Christus te verkondig, nie net as die Heer nie, maar ook as die Verlosser van die wêreld. Die christen is nie geroepe tot enige iets anders as hoop vir homself en vir die wêreld nie ${ }^{78}$ ). Hy is geroepe om wat hy vir homself hoop, ook vir elke ander mens te hoop ${ }^{i 9}$ ). Daarom wil Barth nie vir of teen die apokatastasis kies nie. Op die vraag of die dreiging aan die einde dalk tog nie uitgevoer sal word en die swaard nie sal kap nie, is Barth se eerste antwoord ${ }^{30}$ ) dat indien dit so sal wees, dit waarlik die openbaring van God se onverwagte genade sal wees waarop ons beslis nie mag reken nie, waarop ons slegs mag hoop. God is aan die mens nie enige geduld of redding verskuldig nie. Ons kan dus wat die alversoening en apokatastasis betref niks postuleer nie - ook nie

\footnotetext{
76. K.D. IV 3, p. 1068v.

$\because$ K.D. IV 1, p. $125,126$.

$\because$ K.D. IV 1, p. 129 .

a. K.D. IV 3, p. 1054

8c. K.D. IV 3, p. 549-550.
} 
onder 'n beroep op die kruis en opstanding van Jesus Christus nie. Ons kan nie teologies konkludeer tot dit wat slegs as vrye gawe geskenk en ontvang kan word nie.

Aan die ander kant het ons geen reg om dit as verbode te beskou om die moontlikheid oop te hou dat die hoogs onverwagse werklikheid kan word deurdat die dreiging nie uitgevoer word nie en alle mense uiteindelik tog gereg kan word nie. „Weist die überlegene . . . Wirklichkeit . . . nicht eindeutig in die Richtung des Werkes einer in der Tat ewigen göttlichen Geduld und Errettung und also einer „Apokatastasis" oder „Allversöhnung"? Verbietet sie uns bestimmt, damit $\mathrm{zu}$ rechnen ... so gebietet sie uns doch wohl noch bestimmter, eben darauf ... zu hoffen, darum zu beten ..."

Ons mag dus nie daarop reken nie, maar ons mag hoop en bid dat alle mense gered sal word.

\section{WAARDERING EN KRITIEK:}

\section{A. WAARDERING:}

\section{DIE ONTWIKKELING VAN BARTH SE ESKATOLOGIESE ONTWERP:}

Soos in sy hele teologie ${ }^{81}$ ), het Barth ook - en veral - in sy eskatologie hoe langer hoe meer sy aanvanklike eensydigheid prysgegee ten gunste van 'n breër en Bybelser visie ${ }^{32}$ ). Aanvanklik het die klem eensydig gelê op die ewigheid wat radikaal „krities" teenoor die tyd staan, op die ewigheid wat ewe naby aan elke oomblik is en op die Parusie wat nie kan uitbly nie omdat dit nie kan intree nie. Barth se transendentale (vertikale) klem - wat op sigself legitiem is en waarop hy as sodanig nie terugkom nie ${ }^{83}$ ) - het nie ruimte gelaat vir 'n horisontale voortgang na die einde nie. Vir 'n toekomsverwagting het sy dialektiek van ewigheid en tyd aanvanklik nie ruimte gebied nie $^{\text {s4 }}$.

Sy ontwikkeling - selfs kentering - via die verskillende stadia tot in K.D. IV 3 het egter al meer die „zeitlichkeit” van die ewigheid beklemtoon en selfs die „ewige tyd" van Jesus

81. Vir sy algemene ontwikkeling - en meer bepaald die kentering en ontwikkeling in sy Godsleer - is sy eie uiteensetting besonder waardevol. Dit staan 0.a. in "The Humanity of God". hoofst. 2, p. 33v.

82. Sy eie weergawe van hierdie kentering sedert die Römerbrief word veral gevind in K.D. II 1.p. 714v.

s. Van hierdie eensydige beklemtoning in 1922 sê hy in 1940: „Well roared, llon! Nichts ist schlechthin falsch in diesen gewagten Sätsen. Ich denke noch jetzt, dass ich damit zehnmal recht hatte gegenüber denen, genen die sie sich damals richteten und die sich damals dagegen auflehnten. . . . dass es damals nötig war, so zu reden." K.D. II 1, p. 715 . Kursivering van Barth.

81. Vergelyk ook die kritiek van J. Moltmann: Theologie der Hoffnung, o.a. p. $33 v$. 
van Nasaret. Hy het al meer oog gekry vir die ewigheid wat in Jesus Christus in die tyd ingegaan het en so aan ons tydelike bestaan deel aan sy ewigheid (naamlik die gawe van dis ewige lewe) gegee het. Dit het, via die geskiedenis wat so meer tot sy reg gekom het, al meer ruimte geskep vir 'n egte toekomsverwagting, vir die teologiese betekenis van uitsprake soos Rom. 13:11-12 $2^{35}$ ). In die uiteindelike ontwerp van die drie vorme van die Parusie van Jesus Christus is vir die geskiedenis en die doel wat bereik word dus veel meer ruimte as wat oorspronklik verwag kan word. Trouens, Barth se posisie in K.D. IV 3 verskil nie meer wesenlik van die heilshistoriese visie op die eskatologie wat na die Tweede Wêreldoorlog sy bloeitydperk beleef in onder andere Cullman en die Wêreldraad van Kerke se publikasies nie $\left.{ }^{86}\right)$.

\section{DIE DRIE VORME VAN DIE PARUSIE:}

Aan die ander kant kan Barth se ontwerp ook nie sonder meer met die gangbare heilshistoriese visie gelykgestel word nie. Allereers omdat hy die eskatologie, histories gesien, veel vroeër laat begin. Hy sien naamlik Christus se opstanding as die begin van die eskatologie ${ }^{8 \tau}$ ), te wete die eerste vorm van die Parusie. Hierin het Barth 'n wins op die heilshistoriese eskatologie. Die eeue-oue probleem dat die eskatologie beperk bly tot 'n slothoofstuk of 'n (redelik onbelangrike) aanhangsel van die dogmatiek ${ }^{\mathrm{s}}$ ), word hier enigsins opgelos deurdat die eskatologie alreeds by die opstanding van Christus begin en gevolglik ook die hele sogenaamde tussentyd (die tyd van die Heilige Gees, die kerk en die sending) insluit. Die eskatologie is dan nie langer beperk tot 'n aantal "dinge" wat „eendag” (gou of later) sal gebeur nie.

85. K.D. II 1, p. 716.

s6. Vergelyk o.a. O. Cullmann: Christus und die Zeit, O. Cullmann: Heil als Geschichte; Christ - The Hope of the World, in: Evanston (Boekencentrum 1954); P. S. Minear: Christian Hope and the Second Coming; J. E. Fison: The Christian Hope; W. Kreck: Die Zukunft des Gekommenen; H. Berkhof: Christus de Zin der Geschiedenis; H .Berkhof: Gegronde Verwachting; G. C. Berkouwer; De Wederkomst van Christus I en II.

87. O.a. K.D. III 2, p. 757, 589; K.D. IV 3, p. 366,341 : „In diesem Sinn ist das Osterereignis das ursprüngliche, weil erste" eschatologische Ereignis". Kursivering van Barth.

88. Vergelyk o.a. J. Moltmann: Theologie der Hoffnung p. 11-12: „So führten diese Lehre vom ende ein eigentümlich steriles Dasein am Ende der christlichen Dogmatik. Sie waren wie ein loser Aanhang, der in apokrypher Unwesentlichkeit verkam ... Eschatologisch ausgerichtet ist vielmehr der Charakter aller christelichen Verkundigung, jeder christlicher Existenz und der ganze Kirche . . Eine rechte Theologie müsste darum von ihrem Zukunftsziel her bedacht werden. Eschatologie soll nicht ihr Ende, sondern ihr Anfang sein". Ook G. C. Berkouwer: De Wederkomst van Christus II, p. 270. 
Alhoewel dit beslis 'n wins op die gewone heilshistoriese benadering is, (byvoorbeeld soos ons dit by Cullman aantref volgens wie Christus die „Mitte der Zeit" is en die eskatologie uitsluitlik toekomsgerig is) sal dit later egter betoog word dat Barth nog nie histories ver genoeg teruggegaan het nie, dat hy naamlik al die Skrifgegewens eers dán sal verdiskonteer as hy ook die inkarnasie, aardse lewe en kruisiging van Jesus Christus eskatologies dui.

'n Verdere verdienste van die drie vorme van die Parusie is dat op hierdie wyse pragtig reg kan geskied aan die Bybelse gedagte wat onder andere deur G. C. Berkouwer na vore gebring is - en seker ongetwyfeld deur Barth breed uitgewerk sou gewees het indien hy ooit sy eskatologie kon voltooi - naamlik dat die wederkoms van Christus nie vreemd en huiweringswekkend vir die gelowiges sal wees nie $\left.{ }^{\mathrm{s}}\right)$. Deur te beklemtoon dat Christus alreeds in twee vorme gekom het én tans by ons is, kan die ,gewoondheid" en troostende karakter van sy wederkoms sterk na vore gebring word. Vergelyk onder andere 1 Thes. 4:18; 5:11.

\section{DIE ONONTBEERLIKHEID VAN EGTE TOEKOMSVERWAG، TING:}

Barth het hoe later hoe sterker daarop klem gelê dat daar géén eskatologie moontlik is sonder 'n egte toekomsperspektiel nie $^{\times 9} \mathrm{a}$ ). (Dit moet onder andere gesien word as 'n aanduiding van hoe sterk sy ontwikkeling - en selfs kentering! - ten opsigte van 1922 was.) Hy verwyt Bultmann c.s. dat alles by hulle eskatologies geword het - die kruis, die opstanding, die geloof, die liefde, die kerygma, die kerk, die doop, die avondmaal, die etiek - „während ein im besonderen Sinn „eschatologischer" Bereich der Hoffnung als der christlichen Zukunfterwartung . . . gewissermassen verdampfte und verschwand"'o0).

Dit is gevolglik duidelik dat veel in Barth se ontwerp vir die eskatologie te waardeer is. Die feit dat sy eskatologiese visies nie so 'n wesenlike invloed op die teologie van die twintigste eeu uitgeoefen het of sal uitoefen nie, is allereers nie te wyte aan bepaalde gebreke nie, maar aan die blote feit dat hy dit nie in besonderhede uitgewerk het nie.

\section{B. KRITIEK:}

Met veel huiwering word hiermee 'n poging aangewend om 'n paar punte van kritiek op Barth se ontwerp vir die eskatologie

к9. De Wederkomst van Christus I, p. 298v. s9(a). Vergelyk nota 21 en II C 2 b 1 par. 2. 9\%. K.D. IV 3, p. 1047. 
uit te spreek. Hierdie huiwering is nog groter in die lig van die feit dat Barth sy eskatologie nie volledig uitgewerk het nie.

\section{Die on-Barthiaanse beperking in Barth se eskatologie:}

Die mees bevreemdende feit van Barth se ontwerp vir die eskatologie is dat hy die eskatologie nie in Jesus Christus fundeer nie maar slegs vanuit sy (drievormige) Parusie struktureer. Tegelyk is die inmiskenbare gevaar van hierdie sentrale kritiek dat Barth - wat deurgaans so wesenlik Christologies gedink het hoogs waarskynlik self hierdie gebrek sou herstel het indien hom die geleentheid gegun was om K.D. $\mathrm{V}$ aan te pak.

Feit bly egter dat 'n bepaalde gebruik van die begrip Parusie die struktuur of ontwerp van Barth se eskatologie bepaal. Hy begin die uiteensetting van sy finale ontwerp met 'n ontleding van die begrip ,parousia" ${ }^{11}$ ) en die invloed wat hierdie begrip in die verdere uiteensetting speel, dui daarop dat Jesus Christus self nie die beslissende fondament vir Barth se eskatologie is nie.

Om hierdie kritiek te verduidelik, wil ek kortliks die eskatologie in Jesus Christus fundeer soos ek meen dat Barth dit in ooreenstemming met die wesenlike inhoud van sy dogmatiek behoort te doen.

Barth sien die skepping as die uiterlike grond van (of ruimte vir) die verbond. God het naamlik besluit om nie sy heerlikheid alleen te geniet nie, maar om 'n wese te maak wat anders as Hy is, om sy heerlikheid met Hom te deel. Die doel van die skepping is dus die verbond: „Ek sal vir julle 'n God wees, en julle sal vir my 'n volk wees". Of anders gesê: die doel van die skepping is „God met ons".

Maar nou is dit duidelik dat dit juis Jesus van Nasaret is wat die vervuller en vervulling van die verbond is. As vere deus et vere homo is Hy onse God en ons verteenwoordiger by God, dit wil sê God se troue bondgenoot in ons plek. In Jesus van Nasaret word die doel van die skepping dus bereik: Immanuel, God met ons. Hierdie doel is juis nie in die Ou Testamentiese geskiedenis van Adam of Israel bereik nie. Trouens die $\mathrm{Ou}$ Testament is juis die geskiedenis van die „onmoontlike moontlikheid" naamlik dat Adam en Israel (as verteenwoordigers en voorbeelde van alle mense) misluk het. Die Ou Testament is dus die geskiedenis van die ontroue bondgenote, van die mislukking van die mense as God se troue bondgenote.

Die geskiedenis van Jesus Christus is dan die geskiedenis van God se skeppingsdoel - die verbond - wat verwesenlik word. (In ooreenstemming hiermee begin Barth dan ook sy versoenings-

91. K.D. IV 3, p. 337v. 
leer met die verbondsleer.) Gevolglik is dit nie bevreemdend dat Jesus die Eschatos (die laaste) genoem word nie. Hy is die doe] wat God met sy skepping beoog en bereik. Hy is dus die fondament en wesenlike inhoud van die ,eskato"-logie - en nie die drie vorme van sy Parusie nie.

In hierdie lig is dit volkome begryplik dat die Nuwe Testament sy inkarnasie, aardse optrede en kruisiging net so radikaal eskatologies sien as sy opstanding, koms in die Heilige Gees en ,laaste wederkoms". Volgens Hebr. 1:1 het God ,,in die laaste dae" tot ons gespreek deur die Seun wat volgens Hebr. 9:26 ,in die voleinding van die eeue verskyn (het) om die sonde deur sy offer weg te doen" en volgens 1 Petrus 1:20, ,in hierdie laaste tye geopenbaar is om julle ontwil". In volle ooreenstemming met hierdie eskatologiese karakter van die inkarnasie verklaar Jesus: „Maar as Ek deur die Gees van God die duiwels uitdryf, dan het die koninkryk van God by julle gekom (Matt. 12:28; vergelyk Luk. 11:20 en 17:21 wat volgens die meeste nuwere vertalings vertaal moet word met iets soos: die koninkryk van God is in julle midde ${ }^{92}$ ). Wie die eskatologiese karakter van die Ou Testamentiese verwagting van die toekomstige heerskappy van God begryp, sal insien dat met hierdie uitsprake op radikale wyse die eskatologiese karakter van Jesus se aardse optrede aangedui is. En in die lig hiervan is Johannes se sogenaamde „presentiese” eskatologie nie meer bevreemdend nie, naamlik "Nou (dit wil sê nog vóór die kruisiging van Jesus!) is dit die oordeel van hierdie wêreld" (Joh. 12:31) en "hy wat nie glo nie, is alreeds veroordeel" Joh. 3:18. Vergelyk ook Joh. 3:36; 1 Joh. 5:11-13.

As Barth dus 'n eskatologie wil skryf wat getrou is aan sy sentrale Christologiese fundering - en na my mening aan die Heilige Skrif - sal hy die hele geskiedenis van Jesus Christus eskatologies dui, en nie eers by sy opstanding begin nie. Trouens dit is nie 'n gedagte wat vreemd is aan Barth se versoeningsleer dat dit eskatologies van karakter is nie. Hy het reg aan die begin van sy versoeningsleer gesê dat die heil wat deur die versoening ons deel word, die mens se "Eschaton" is ${ }^{93}$ ). Slegs twee bladsye verder praat hy weer van "God-met-ons" en die heil wat daardeur ons deel word, as "Eschaton". Trouens wanneer hy in hierdie verband handel oor die versoening as meer as 'n „restitutio ad integrum" verklaar hy: die versoening is: „die Gegenwart des Eschaton in seiner ganzen Fülle"04), en: „Nicht ein Vorletztes,

92. O.a. N.B.G., P.C., Willibrord, N.E.B. Net T.E.V. vorm 'n uitsondering op hierdie reël, $\in$ n volg die Afrikaanse Vertaling: „Want die Koninkryk van God is binne-in julle".

9. K.D. IV 1, p. 7.

94. Idem., p. 13 . 
sondern ein Letztes geschieht ja in der durch ihn vollzogenen Versöhnung"95).

Barth het dus die aanleiding in hierdie uitsprake gehad om die hele geskiedenis van Jesus Christus eskatologies te dui. Hy doen dit egter nie. Hy trek nie die konklusies wat kragtens sy hele teologiese stelsel voor die hand lê nie, en uitsprake soos Hebr. 1:1, 9:26; Petr. 1:20, Matt. 12:28; Luk. 11:20; 17:21 word nie in sy dagmatiek verdiskonteer nie. Hy beperk, inteendeel, die eskatologie tot 'n bepaalde deel van die geskiedenis van Jesus Christus (die deel wat hy as sy radikaal nuwe, ander, tweede geskiedenis sien, naamlik sy geskiedenis wat by sy opstanding begin) en bevry gevolglik tog nie die eskatologie werklik van sy slothoofstuk-karakter nie.

Dit sou besonder moeilik wees om die motivering vir hierdie beperking van die eskatologie by Barth aan te toon. Maar die vermoede leef by my dat dit saamhang met 'n ander onderskeiding wat eweneens onaanvaarbaar is, naamlik dat die eskatologie uitsluitlik noëties (en nie onties) van karakter is.

\section{Die karakter van die eskatologie: noëties of ook onties?}

Met veel klem leer Barth dat die eskatologie uitsluitlik 'n noëtiese karakter dra. „Die Osterzeit ist also schlicht: die Zeit der Offenbarung des Geheimnisses der ihr vorangehenden Zeit des Lebens und Sterbens des Menschen Jesus" ${ }^{\prime 96}$ ). Tydens Jesus se lewe het die koninkryk van God alreeds gekom en was dit dus alreeds 'n werklikheid - egter nog 'n verborge werklikheid. Sy opstanding (en die ander vorme van sy Parusie) openbaar egter hierdie werklikheid ${ }^{97}$ ). Later herhaal hy: „Eben das geschah in seinem neuen Kommen, in seinem Heraustreten aus dem Heer der Toten: dass die in ihm schon vollzogene Veränderung der Situation zwichen Gott und Welt dadurch aktualisiert wurde, dass sie auch in noetischer Gestalt . . . unmittelbar und volkommen Ereignis wurde, ihrer Verborgenheit entnommen, der Welt offenbar und bekannt gemacht ... " ${ }^{98}$ ).

Barth beperk dus die ontiese karakter van Jesus se geskiedenis tot sy lewe en kruisiging. Dáár het die werklike verandering plaasgevind. Dáár is die doel bereik. Dáár is die wêreld met God versoen. Die opstanding (en die res van Jesus se geskiedenis) maak slegs hierdie voltrokke verandering bekend.

\footnotetext{
9. Idem., p. 36.

mi. K.D. III 2. p. 546.

oi. Idem.. p. 599. Kvk veral ook K.D. IV 3, p. 1051.

09. K.D. IV 3, p. 342.
} 
Aangesien die eskatologie by Barth eers by die opstanding van Christus begin, beteken dit dat die eskatologie geen ontiese (werklikheids-) karakter dra nie, maar dat eksatologie slegs die bekendmaking is van wat alreeds werklik is. Dit is egter ' $n$ hoogs bevreemdende standpunt. Dit beteken dat die feit dat die doel bereik is (in die lewe en kruis van Jesus), geen eskatologiese waarde het nie. Eers die bekendmaking van die feit dat die doel bereik is, is eskatologie. Dit lyk nie 'n aanvaarbare posisie nie.

$U$. Hedinger het beweer dat Barth dan ook inderdaad nie daarin slaag om sy eksatologie tot 'n bloot noëtiese daad te beperk nie ${ }^{99}$ ), en dat dit in elk geval ook 'n illegitieme poging is, aangesien die hoop sig nie slegs rig op dit wat nog vervul en verborge is nie, „,sondern auf noch Ausstehendes". Immers geloof rig sig op die onsigbare „Gegenwart”, maar hoop op dit wat nog nie "Gegenwart" is nie. Hy beroep hom veral op die kosmiese aspekte van die voleinding. Hier kom veral die opstanding van die dode asook die nuwe hemel en die nuwe aarde ter sprake. Dit gaan in hierdie eskatologiese verwagting inderdaad om 'n ontiese verwagting. Die nuwe aarde en ons opstandingsliggaam bestaan nog nie. Dit moet nie slegs nog geopenbaar of onthul word nie.

Ook J. Moltmann lewer in hierdie opsig op Barth (en op sy navolger W. Kreck) kritiek: „Die christliche Erwartung dichtet sich auf niemand anderen als auf den gekommen Jesus, aber sie erwartet von ihm Neues, bisher noch nicht Geschehenes . . ."100).

In hierdie lig lyk dit geregverdig om Barth se eskatologiese ontwerp in hierdie opsig op twee punte te korrigeer:

Allereers rnoet die lewe en kruis van Jesus eskatologies gedui word. Dit is onbegryplik dat die radikale verandering en die doel van God bereik kan word (soos Barth die kruis sien) sonder dat dit eskatolcigie genoem kan word.

Verder moet aan die toekomsverwagting ook 'n ontiese karakter toegeken word - sonder om die noëtiese aspek te ontken. Dit waarop die kerk nog wag, is meer as net bekendmaking van wat klaar gerealiseer is. Trouens dit is telkens uit die K.D. self duidelik dat Barth 'n suiwer noëtiese eskatologiese 'n te enige keurslyf vind. Wanneer hy oor die opstanding van Christus as alreeds die voleinding handel, verklaar hy byvoorbeeld: „Neue Schöpfung ist in Jesus Christi Auferstehung geschehen"101). Trouens Barth praat self ook van die wederkons

\footnotetext{
:9. U. Hedinger: Der Freiheitsbegriff in der Kirchlichen Dogmatik Karl Barths, p. $151 \mathrm{v}$.

: (a). Vergelyk II B 2.

ir. Theologic der Hoffnung, p. 207-209.

101. K.D. IV 3, p. 346.
} 
van Christus as die groot lig wat die ganse kosmos sal ver'ig, ,in welchen alles Sterbliche Unsterblichkeit, alles Verwesliche Unverweslichkeit anziehen und haben, in welchen Gott Alles in Allem werden und sein wird. Noch können wir dieses Ereignisses, der Heilszukunft in dieser ihrer abschliessenden und vollkommenen Gestalt tatsächlich erst warten ... so gewiss wir ja dem, was wir noch nicht sind, sondern erst einst, in jener noch ausstehendenden Gegenwart der Heilszukunft sein werden, von dem her entgegensehen und entegengehen dürfen, was wir im Licht des Ostertages schon sind"102).

Die twee voorgestelde korreksies op Barth se eskatologiese ontwerp (naamlik die erkenning van die inkarnasie, aardse optrede en kruis van Jesus as eskatologie, en die erkenning dat ók die toekomsverwagting van die kerk ontiese elemente insluit) sal meebring dat die kruis en opstanding van Christus meer as 'n eenheid gesien word as wat in Barth se dogmatiek gebeur. Hy skei hierdie twee gebeurtenisse deur aan die eerste een ontiese betekenis toe te ken - maar dit nie onder die eskatologie in te sluit nie - en die tweede uitsluitlik noëties te dui maar dan as die begin van die eskatologie.

Hierdie skeiding tussen kruis en opstanding is kunsmatig. In die Nuwe Testament kom hulle veel meer in een asem voor, byvoorbeeld Rom. 4:25; 6:1-11. Dit is opvallend dat Luther (wat beide kruis en opstanding sterk eskatologies gedui het) ${ }^{103}$ ) kruis en opstanding veel meer as 'n eenheid sien ${ }^{104}$ ) en dan die eskatologie juis by die kruis laat begin. „Mit diesem Kreuz ist das Eschaton hereingebrochen"105). Hierdie visie van Luther mag help om bepaalde eensydighede in Barth se eskatologiese ontwerp uit te skakel.

\section{Apokatastasis of nie?}

Onder II C 26 iii (Die Hoop vir die Wèreld) is ruim aangehaal uit K.D. IV 3 oor wat Barth in eskatologiese verband oor die apokatastasis sê. Dit word tans as gelese veronderstel en dus nie herhaal nie.

Oor Barth en die alversoening was al veel te doene. In meer as een locus van die dogmatiek (byvoorbeeld die leer oor God en

\footnotetext{
1112. Idem., p. 368.

1113. U. Asendorf: Eschatologic bei Luther: ..Durch Christus und mit ihm sind wir in den Raum der Letzten Dinge hineingestellt. Kreuz und Auferstehung sind das Anfangsdatum der Eschatologie". p. 13 .

114. Idem., 0.a. p. 16, 125. Vergelyk ook J. T. Bekker: Eschatologische Prediking by Luther, p. 31-32.

105. Idem., p. 13.
} 
die leer oor die versoening) is Barth al hierdie leer verwyt en het hy al ontken dat hy dit leer. Nêrens elders het hy egter so kort en helder sy standpunt uiteengesit as in K.D. IV 3 p. 550 nie. Hieruit val met sekerheid te konstateer dat Barth nie 'n apokatastasis (of alsaligheid) leer nie, maar wel daarvoor bid en hoop - en dat hy oortuig is dat dit ons beslis gebied word om daarvoor te hoop en te bid. Immers: „Verbietet sie aus bestimmt damit zu rechnen,... so gebietet sie uns noch wohl noch bestimmter eben darauf . . . zu hoffen und darum zu beten".

Dit is moeilik om hierdie standpunt te beoordeel. Dit herinner ongetwyfeld aan uitsprake soos II Petr. 3:9: " . . . Hy is lankmoedig oor ons en wil nie hê dat sommige moet vergaan nie, maar dat almal tot bekering moet kom." Maar nogtans ontkom mens nie die indruk dat hierdie en soortgelyke tekste anders funksioneer in die Nuwe Testamentiese prediking as by Barth nie. Ondanks die feit dat die Nuwe Testament telkens ons blik op die grootheid van Gods genade vir die hele wêreld rig, hou dit veel meer reëel rekening met mense, selfs die meerderheid van die mense, wat verlore gaan. Mens ontkom nie aan hierdie indruk as mens die beelde lees waaronder die eindbestemming van die wêreld en veral die laaste oordeel beskryf word nie. Byvoorbeeld Matt. 7:13-14 (,Gaan in deur die nou poort, want breed is die poort en wyd is die pad wat na die verderf lei, en daar is baie wat daardeur ingaan”); Matt. 7:22-23 („Baie sal in daardie dag vir My sê: Here, Here ... En dan sal Ek aan hulle sê: Ek het julle nooit geken nie, Gaan weg van My, julle wat die ongeregtigheid werk"); Matt. 26:41 (,Dan sal Hy ook vir die aan sy linkerhand sê: Gaan weg van My, julle vervloektes, in die ewige vuur wat berei is vir die duiwel en sy engele"); Matt. 26:46 (,En hulle sal weggaan in die ewige straf maar die regverdiges in die ewige lewe"); II Thes. 1:7-9; Openb. 20:10, 15; 21:8. Mens ontkom nie aan die indruk dat hierdie uitsprake net so werklik rekening hou met die saligheid van mense as met die ewige verderf van ander mense nie.

Dit neem die feit nie weg dat ons moet waak teen 'n sadistiese prediking van die toorn van God soos die Middeleeuse skilderye van die oordeel dit voorstel nie. Dit neem ook nie die feit weg dat ons moet nadink oor wat Barth eenmaal geantwoord het op die herhaalde klag teen hom dat hy die alsaligheid leer nie: Dit lyk of bepaalde teoloë se grootste bekommernis is dat die hemel eendag te vol en die hel te leeg gaan wees.

Mag dit nie van ons waar wees nie!

Maar hierdie belangrike feite doen niks af aan die gevaar van 'n valse hoop op Barth se standpunt nie. Die opdrag van die Bybel om vir alle mense te bid en om van alle nasies sy dissipels 
te maak, gaan gepaard met 'n veel reëler waarskuwing vir die ewige verderf as die indruk wat deur Barth se verwysing na die grootheid en onverwagsheid van God se genade in hierdie verband gemaak word. Die grootheid van God se genade wil niemand betwyfel nie. Maar dat hierdie groot genade op 'n bepaalde punt in die teologie anders kan funksioneer as in die Bybel, is ' $n$ reële gevaar. Konkreter gesê: Jesus Christus is inderdaad die Verlosser van die wêreld. In Hom het God inderdaad die wêreld met Homself versoen. Maar hierdie waarheid funksioneer op ' $n$ heel bepaalde wyse in die Skrif, en wel só dat die konkrete waarskuwing teen die ewige verderf nooit skuil gaan agter God se versoening in Jesus nie.

Uit die enkele punte van kritiek wat gelewer is, blyk dit slegs nog duideliker hoe jammer dit is dat Barth sy eskatologie nie kon voltooi nie. Want al sou dit waar wees dat daar enkele punte is waarin hy anders dink as die Nuwe Testament, dan mag mens nooit vergeet dat haas elke ontwikkeling wat sig in die afgelope 50 jaar in Barth se teologiese aktiwiteit voltrek het, 'n ontwikkeling (of selfs 'n kentering) nader aan die Bybelse boodskap was. Waarom sou dit in hierdie opsig anders gewees het?

\section{Bibliografie}

1. U. Asendorf: Eschatologie bei Luther, Vandenhoek und Ruprecht, 1967. J. T. Bakker: Eschatologische Prediking by Luther, Kok, 1964.

3. K. Barth: Der Römerbrief - Unveränderten Nachdruk der ersten Auflage von 1919 E.V.Z., 1963.

'. K. Barth: Der Römerbrief - Neunter Abdruck der neuen Bearbeitung, E.V.Z., 1954.

5. K. Barth: Kirchliche Dogmatiek II 1, III 1, III 2, IV 1, IV 3, IV 4, E.V.Z. 1940 en later

$\therefore$ K. Barth: The Humanity of God. Fontana, 1960.

7. H. Berkhof: Christus de Zin der Geschiedenis, Callenbach.

* H. Berkhof: Gegronde Verwachting, Callenbach, 1967.

. G. C. Berkouwer: De Wederkomst van Christus I en II, Kok, 1961 en 1963.

11. O. Cullmann. Christus und die Zeit, E.V.Z.. 1946.

11. O. Cullmann: Heil als Geschichte, J. C. B. Mohr, 1965.

12. Evanston, Boekencentrum, 1954.

13. J. E. Fison: The Christian Hope. Longmans. 1954.

11. U. Hedinger: Der Freiheitsbegriff in der Kirchlichen Dogmatiek Karl Barths, Zwingli, 1962.

1. P. S. Minear: Christian Hope and the Second Coming, Westminister 1953.

15. J. Moltmann: Theologie der Hoffnung, Chr. Kaiser, 1966.

1i. Vox Theologica 37/4/Juli 1967.

1s. W. Kreck: Die Zukunft des Gekommenen, Chr. Kaiser, 1961. 